\title{
Extracellular Vesicles in Alzheimer's and Parkinson's Disease: Small Entities with Large Consequences
}

\author{
Charysse Vandendriessche ${ }^{1,2} \oplus$, Arnout Bruggeman ${ }^{1,2,3} \oplus$, Caroline Van Cauwenberghe ${ }^{1,2}(\mathbb{D}$ \\ and Roosmarijn E. Vandenbroucke ${ }^{1,2, * \mathbb{D}}$ \\ 1 VIB Center for Inflammation Research, VIB, 9052 Ghent, Belgium; \\ charysse.vandendriessche@irc.VIB-UGent.be (C.V.); arnout.bruggeman@irc.VIB-UGent.be (A.B.); \\ caroline.vancauwenberghe@irc.VIB-UGent.be (C.V.C.) \\ 2 Department of Biomedical Molecular Biology, Ghent University, 9000 Ghent, Belgium \\ 3 Department of Neurology, Ghent University Hospital, 9000 Ghent, Belgium \\ * Correspondence: roosmarijn.vandenbroucke@irc.VIB-UGent.be; Tel.: +32-9-3313730
}

Received: 17 October 2020; Accepted: 10 November 2020; Published: 15 November 2020

\begin{abstract}
Alzheimer's disease (AD) and Parkinson's disease (PD) are incurable, devastating neurodegenerative disorders characterized by the formation and spreading of protein aggregates throughout the brain. Although the exact spreading mechanism is not completely understood, extracellular vesicles (EVs) have been proposed as potential contributors. Indeed, EVs have emerged as potential carriers of disease-associated proteins and are therefore thought to play an important role in disease progression, although some beneficial functions have also been attributed to them. EVs can be isolated from a variety of sources, including biofluids, and the analysis of their content can provide a snapshot of ongoing pathological changes in the brain. This underlines their potential as biomarker candidates which is of specific relevance in AD and PD where symptoms only arise after considerable and irreversible neuronal damage has already occurred. In this review, we discuss the known beneficial and detrimental functions of EVs in $\mathrm{AD}$ and $\mathrm{PD}$ and we highlight their promising potential to be used as biomarkers in both diseases.
\end{abstract}

Keywords: extracellular vesicles; Alzheimer's disease; Parkinson's disease; biomarkers

\section{Introduction}

Alzheimer's disease (AD) and Parkinson's disease (PD) are the two most common neurodegenerative disorders characterized by the misfolding, aggregation and widespread accumulation of natively unfolded proteins $[1,2]$. In the case of $A D$, amyloid beta $(A \beta)$ deposits into extracellular $A \beta$ plaques, whereas the hyperphosphorylation of the protein Tau leads to the formation of neurofibrillary tangles inside neurons [3]. These lesions lead to the loss of synapses and neurodegeneration which result in the symptoms associated with AD [4]. In PD, the protein alpha-synuclein ( $\alpha$-syn) aggregates into intraneuronal Lewy bodies and Lewy neurites [5]. The second neuropathological hallmark of PD is the loss of dopaminergic neurons in the substantia nigra pars compacta, leading to functional impairment of the nigrostriatal pathway and the occurrence of the cardinal motor symptoms [6]. Interestingly, the Tau and $\alpha$-syn pathology spreads throughout the brain in a predictable, characteristic pattern $[7,8]$. This is thought to be the result of their cell-to-cell transmission in a prion-like fashion, whereby the pathologic aggregates from the donor neuron induce the misfolding of their endogenous counterparts in the acceptor neuron [9]. In contrast to Tau pathology, amyloid plaques display a less predictable spreading pattern whereby their presence does not correlate well with cognitive decline either $[10,11]$. Consequently, the research focus has shifted towards soluble $A \beta$ oligomers ( $A \beta O s$ ) as being the main neurotoxic $A \beta$ conformation capable of inducing synaptic 
dysfunction [11,12]. These oligomers also appear to be the most potent conformation related to the proposed hypothesis of prion-like spreading of $A \beta$ pathology [13]. Although the exact spreading mechanism of these disease-related proteins is not completely understood, extracellular vesicles (EVs) have been proposed as one of the contributors [14].

EVs are nanosized membrane vesicles that can be classified as exosomes or microvesicles based on their mode of biogenesis. They are important mediators of intercellular communication due to their capacity to transfer proteins, lipids and genetic material to both adjacent and distant cells whereby they influence various physiological and pathological functions [15]. Although a major part of the research cited in this review utilizes specific nomenclature to describe EV subtypes, we decided to consistently use the general term "EVs". The rationale behind this is that it is currently still very difficult to discriminate between EV subtypes due to the lack of subtype-specific markers [16]. In this review, we first discuss the role of EVs in AD. Hereby, we elaborate on how the proteolytic cleavage of the amyloid precursor protein (APP) can lead to the release of $A \beta$ in association with EVs whereafter we review the known beneficial and detrimental functions of EVs in AD. Next, we discuss the role of EVs in the pathogenesis of PD. Finally, we focus on how these EVs provide exciting opportunities to be used as biomarkers in both diseases.

\section{The Role of EVs in AD}

\subsection{The Convergence between the Generation of $A \beta$ and $E V S$}

$A \beta$ is released by proteolytic processing of APP which can occur in a non-amyloidogenic or amyloidogenic fashion [17-19]. The difference between both pathways can be attributed to the initial cleavage step by either $\alpha$-secretase or $\beta$-secretase, respectively. The former cleavage occurs within the $A \beta$ domain and thereby prevents the formation of a full-length $A \beta$ peptide. Subsequently, the large $N$-terminal ectodomain, called soluble $\operatorname{APP} \alpha(\operatorname{sAPP} \alpha)$, is released, whereas the $\alpha$-C-terminal fragment ( $\alpha$-CTF or C83) remains bound to the membrane. Alternatively, the cleavage by the $\beta$-secretase, called $\beta$-site APP cleaving enzyme-1 (BACE1), results in the formation of SAPP $\beta$ and $\beta$-CTF that consists of 99 amino acids (C99). The next cleavages occur within the transmembrane domain of $\alpha$-CTF or $\beta$-CTF and are mediated through the $\gamma$-secretase complex. This leads to the release of the cytoplasmatic APP intracellular domain (AICD) and either P3 $\left(\mathrm{A} \beta_{17-40 / 42}\right)$ in the non-amyloidogenic pathway or a longer $A \beta$ species (including but not limited to $A \beta_{1-38 / 40 / 42}$ ) in the amyloidogenic pathway [20]. The difference in length of the secreted $A \beta$ peptide is attributed to the different positions where the sequential $\gamma$-secretase cleavages can occur, with $A \beta_{1-40}$ being the most prevalent product that is generated. However, in $\sim 10 \%$ of the cases, $A \beta_{1-42}$ is formed, which is considered to be more directly related to AD pathology since it is more hydrophobic, aggregation prone and the major constituent of amyloid plaques [12,21].

Both APP and the secretases traffic through multiple cellular compartments and co-localize at several locations, although the exact processes are not completely unraveled. However, the following routes leading to non-amyloidogenic processing at the plasma membrane and amyloidogenic processing in intracellular compartments are generally proposed [18,19,22,23] (Figure 1). After its synthesis in the endoplasmic reticulum (ER), APP is transported through the Golgi compartment to the plasma membrane, where it is rapidly cleaved by $\alpha$-secretase or re-internalized in endosomes. Alternatively, APP can directly be transported from the trans-Golgi network (TGN) to endosomes. These endosomes can recycle to the plasma membrane, undergo retrograde transport to the TGN or mature into late endosomes which can fuse with lysosomes for degradation. Additionally, the endosomes provide an acidic environment which is known to be ideal for BACE1 activity, hence leading to the amyloidogenic processing of APP. The active $\gamma$-secretase complex is thought to be principally localized to the plasma membrane and in the endosomal/lysosomal compartments, complementing the activity of $\alpha$ - and $\beta$-secretase, respectively, at these locations [18]. Little is known about how the intracellularly generated $A \beta$ peptides are released into the extracellular 
compartment [23]. One option involves post-Golgi network transport pathways to the plasma membrane, but also the secretion of $A \beta$ via EVs has gained attention [23]. In this context, it is interesting to know that late endosomes, which are also called multivesicular bodies (MVBs), can have multiple destinations: they can either fuse with the lysosome, resulting in degradation, or they can fuse with the plasma membrane, thereby releasing their intraluminal vesicles (ILVs) as EVs into the extracellular environment [15].

Several studies suggest detrimental effects of altering the trafficking of APP in AD pathogenesis with a central role for MVBs. Experiments in several APP-expressing cell lines and primary cortical neurons indicate that the sorting of APP to ILVs in a subset of MVBs occurs via the endosomal sorting complexes required for transport (ESCRT) pathway $[24,25]$ and is dependent on the ubiquitination of APP [24]. Furthermore, the trafficking of APP into EVs has also been reported to be dependent on an Alix-Syntenin-1 pathway, independent of the ESCRT machinery [26]. In general, MVBs formed by the ESCRT-dependent pathway are destined for lysosomal degradation [15]. Indeed, the direct (i.e., via Hrs and Tsg101, both key players in the ESCRT pathway) and indirect (i.e., via Vps34, the main source of phosphatidylinositol-3-phosphate (PI3P)—see below) inhibition of the ESCRT pathway results in accumulation of APP in enlarged endosomes [24], whereas it reduces the lysosomal delivery of APP, leading to intracellular A $\beta$ accumulation [25]. The reported resulting effect on secreted $A \beta$-levels is contradictory, namely increased [24] or decreased $[25,27,28]$. Interestingly, the levels of PI3P are decreased in affected brain regions of late-onset AD patients and several transgenic mice models of AD [24]. One of the functions of PI3P is its involvement in the recruitment of ESCRT complexes that mediate the intraluminal sorting of ubiquitinated cargo proteins in MVBs. Therefore, it can be speculated that reduced PI3P levels cause a decreased degradation of APP and its metabolites in lysosomes, leading to intracellular $A \beta$ accumulation and/or EV secretion as an alternative cellular route for the MVBs. Furthermore, the intracellular A $\beta$ accumulation might be enhanced due to an increased residence time of APP in endosomal compartments which harbor favorable conditions for amyloidogenic processing. In line with these hypotheses, PI3P depletion in primary mouse cortical neurons results in the intracellular accumulation of APP-CTFs due to decreased lysosomal degradation [28]. This is associated with a sphingolipid-dependent release of APP-CTF-containing EVs, which is suggested by the authors to be a way of disposing of undigested material [28]. Similarly, compromising the function of the lysosome in H4 glioblastoma cells expressing a pathogenic PS1 mutation significantly increases both the release of EVs and the concentration of A $\beta$ associated with EVs [29].

The presence of several products of the APP metabolism in MVBs and EVs is reported by other studies as well. APP and APP-CTFs have been detected in MVBs in cultured human cerebrovascular cells [30] and in cortical neurons of $\mathrm{APP}_{751 \mathrm{SL}} / \mathrm{PS}_{\mathrm{M} 146 \mathrm{~L}}$ mice [31], respectively. In APP-expressing neuroblastoma SH-SY5Y cells, both APP itself, APP-CTFs and AICD are present in MVBs and on secreted EVs that were isolated from the culture medium [32]. In neuroblastoma N2a cells expressing the Swedish mutant form of APP ( $\left.\mathrm{APP}_{\text {Swe }}\right)$, a minor fraction of the $\mathrm{A} \beta$ peptides present in MVBs is released in association with EVs [33]. Another study showed that EVs isolated from these $\mathrm{APP}_{\mathrm{Swe}}$-expressing neuroblastoma N2a cells contain APP, $\alpha$-CTF, $\beta$-CTF and A $\beta_{1-40 / 42}$. In contrast, $\beta$-CTF and A $\beta_{1-40 / 42}$ were respectively absent and lowered in EVs isolated from $\mathrm{APP}_{\mathrm{WT}}$-expressing cells, whereas no difference in the total amount of secreted EVs was detected [34]. Strikingly, the APP and/or CTFs inside the EVs could be processed by $\gamma$-secretase of recipient cells, signifying that EVs can indeed act as vehicles for the intercellular transport of APP and its metabolites [34]. APP and $\beta$-CTF were detected in EVs secreted by $\mathrm{APP}_{\text {Swe }}$-expressing HEK293 and neuroblastoma SH-SY5Y cells as well [26]. Additionally, in vivo experiments show that EVs isolated from the hippocampus of AAV-C99-expressing mice are enriched in $\alpha$-CTFs and $\beta$-CTFs compared to controls. This is even more pronounced upon treatment with a $\gamma$-secretase inhibitor, which also leads to the presence of higher molecular weight CTF species inside the EVs [35]. Furthermore, EVs isolated from brain lysates of Tg2576 mice were shown to contain APP, APP-CTFs and A $\beta$. The levels of APP and APP-CTFs inside these EVs are higher 
compared to the levels in EVs isolated from non-transgenic littermates. The APP-CTFs are enriched in EVs compared to cell lysates, but no differences in the total amount of EVs were reported [36].
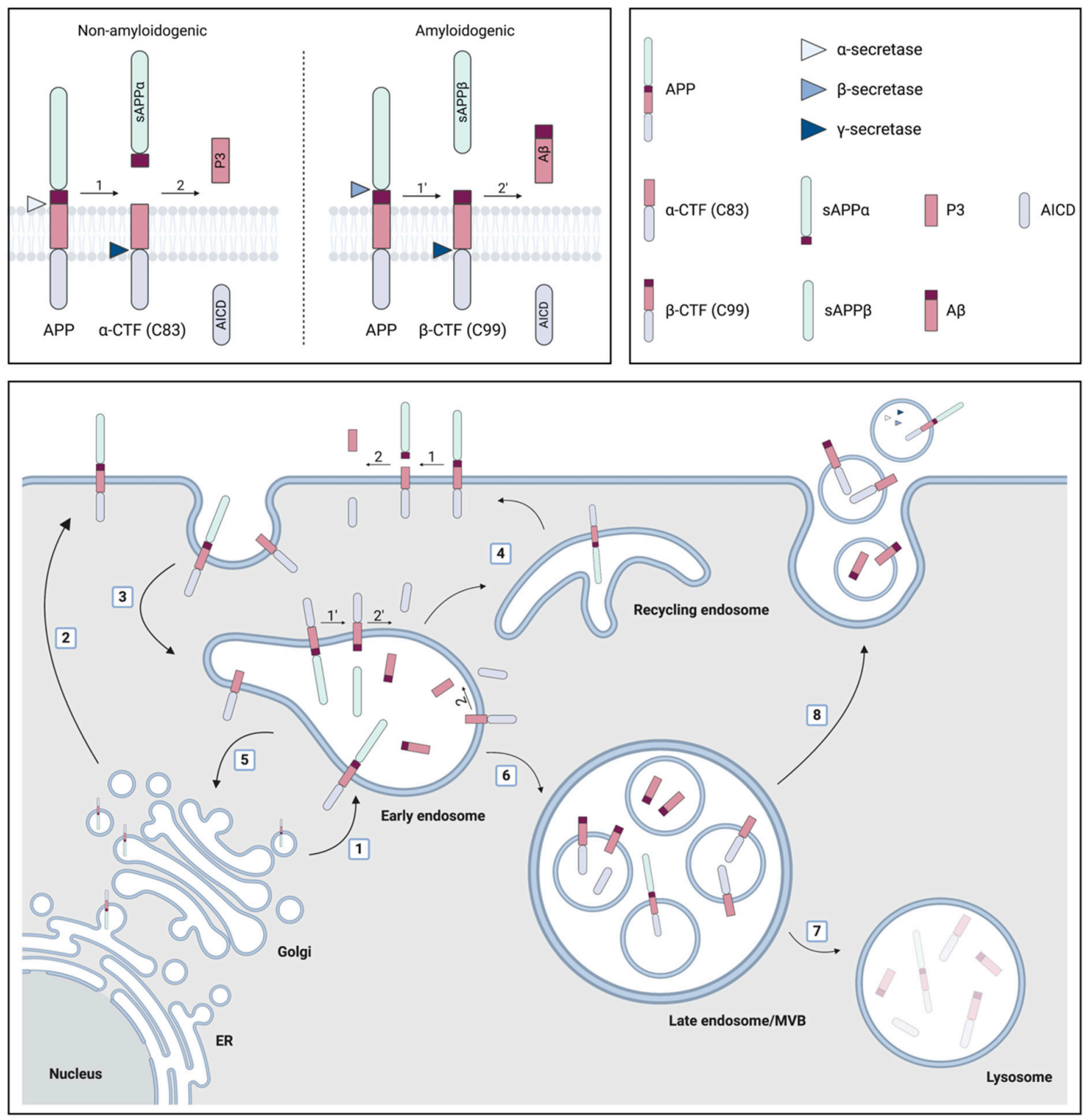

Figure 1. The role of multivesicular bodies (MVBs) and extracellular vesicles (EVs) in amyloid precursor protein (APP) processing. APP is synthesized in the endoplasmic reticulum (ER) and subsequently transported through the Golgi compartment to early endosomes (1) or the plasma membrane (2), where it can be cleaved by $\alpha$-secretase in the non-amyloidogenic pathway. This cleavage leads to the formation of soluble APP $\alpha(\mathrm{sAPP} \alpha)$ and the $\alpha$-C-terminal fragment ( $\alpha$-CTF or C83). Alternatively, APP can be re-internalized in endosomes (3) where the amyloidogenic cleavage by $\beta$-secretase preferentially occurs. Thereby, sAPP $\beta$ and $\beta-\mathrm{CTF}$ (C99) are generated. The formation of the APP intracellular domain (AICD) and either the $\mathrm{P} 3$ fragment or the amyloid $\beta(\mathrm{A} \beta)$ peptide from $\alpha$ - and $\beta$-CTF, respectively, requires cleavage by the $\gamma$-secretase complex. Early endosomes recycle to the plasma membrane (4), undergo retrograde transport to the trans-Golgi network (5) or mature into late endosomes/MVBs (6). The latter either fuse with lysosomes (7) or with the plasma membrane (8), resulting in the extracellular release of their intraluminal vesicles (ILVs) as EVs. Several products of the APP processing pathway have been localized to MVBs (i.e., APP itself; $\alpha$ - and $\beta$ - CTF; AICD; A $\beta$ ) and EVs (i.e., APP itself; $\alpha$ - and $\beta$ - CTF; $A \beta ; \alpha-, \beta$ - and components of the $\gamma$-secretase complex), whereby $\mathrm{A} \beta$ can be localized both on the inside and on the surface of EVs. Figure created with BioRender. 
MVBs also appear to play an important role in the final cleavage step of the APP proteolysis pathway that leads to the release of $A \beta$ peptides. This cleavage is mediated by the $\gamma$-secretase complex which consists of four subunits including presenilin (PS1 or PS2, encoded by PSEN1 and PSEN2). It has been shown that depending on the PS subunit, the subcellular localization of the $\gamma$-secretase complex differs [37]. If the $\gamma$-secretase complex contains PS2, it localizes specifically to late endosomes/MVBs and lysosomes whereas, in the case of PS1, it is more broadly distributed throughout the cell, including the plasma membrane. Strikingly, the $\gamma$-secretase cleavage in late endosomes/MVBs and lysosomes generates an intracellular pool of longer $A \beta$ species. Familial AD (FAD) mutations in PSEN2 increase the intracellular $A \beta_{1-42} / A \beta_{1-40}$ ratio even more dramatically. Moreover, FAD mutations in PSEN1 change its subcellular localization towards that of PS2, similarly promoting the generation of intracellular $A \beta_{1-42}$ species [37]. Interestingly, even prior to the formation of amyloid plaques, $\mathrm{A} \beta_{1-42}$ was shown to accumulate in intraneuronal MVBs of Tg2576 mice and this accumulation increased which age [38]. This suggests that intracellular $A \beta$ accumulation is a very early event in the pathogenesis of $A D$. Other studies reported the presence of $A \beta$ in intraneuronal MVBs in Tg2576 mice, both in vivo $[25,38]$ and in vitro $[39,40]$, in APPxPS1 mice [31] and in the human AD brain $[38,41]$. Moreover, the aggregation of $\mathrm{A} \beta$ peptides has been shown to occur in acidic cellular compartments, including late endosomes, inside neurons [42,43]. This indicates that MVBs are important cellular compartments for both the generation, aggregation and accumulation of $A \beta$ peptides. Additionally, intracellular A $\beta$ accumulation inside MVBs has been shown to affect the MVB sorting pathway as well [40]. Although the sequence and the interplay between the described events remain elusive, they suggest a feedback loop between aberrant subcellular trafficking of APP, intracellular $A \beta$ accumulation and a dysfunction in the endolysosomal-autophagic system, the latter known to be an early pathological feature of AD [44]. Importantly, MVBs appear to be a central intracellular compartment at the intersection of these events, harboring $A \beta$ and other products of the APP metabolism and providing a secretory mechanism for these components under the form of EVs. Interestingly, BACE1, a disintegrin and metalloprotease 10 (ADAM10) and nicastrin, a component of the $\gamma$-secretase complex, were shown to be present in EVs isolated from brain lysates of Tg2576 mice, indicating that the metabolic processing of APP could also occur here [36]. The latter was confirmed in a later study, where it was shown that APP present in brain-derived EVs isolated from Tg2576 mice and incubated in vitro in the absence of cells is cleaved to generate APP-CTFs and AICD [45]. Similarly, EVs isolated from APP-expressing Chinese hamster ovary (CHO) cells contain APP, APP-CTFs, A $\beta$ and the secretases BACE, ADAM10, PS1 and PS2, although nicastrin could not be detected in this study [46]. Altogether, it is clear that EVs are linked with the A $\beta$-generating pathway that plays a central role in the pathogenesis of AD. In the next part of this review, we will discuss both the beneficial and detrimental roles that have been attributed to EVs in AD.

\subsection{The Beneficial Roles of EVs in $A D$}

In wild-type (WT) rats, synaptic disruption caused by the intracerebroventricular (icv) infusion of $\mathrm{A} \beta$-containing human $\mathrm{AD}$ brain extracts was abrogated by EVs derived from N2a neuroblastoma cells or cerebrospinal fluid (CSF) from healthy donors. This protective effect was obtained when the EVs were either pre-infused or pre-incubated with the extracts and is likely due to the sequestration of $A \beta$ assemblies on the surface of the EVs [47]. Along these lines, another study reported that $\mathrm{N} 2 a$-derived EVs promote $A \beta$ amyloidogenesis of both synthetic and endogenous $A \beta$, resulting in the formation of $A \beta$ assemblies associated with EVs which can be more efficiently taken up and degraded by microglia in vitro [48]. According to the authors, the rationale behind this is that EVs accelerate the formation of non-toxic amyloid fibrils, thereby resulting in a decline of the formation of toxic oligomeric species [48]. Similarly, EVs derived from N2a cells [49] and astrocytes [50] were shown to catalyse the aggregation of $A \beta$ in vitro $[49,50]$ and in vivo [50]. However, in these reports, this resulted in a reduced uptake by N2a cells [49], accompanied by a reduced toxicity, and primary mixed glial cultures [50]. This might be explained by the notion that $A \beta$ fibrils are less efficiently taken up by 
target cells than $\mathrm{A} \beta \mathrm{O}$ [51], whereby intracellular $\mathrm{A} \beta$ can have pathological consequences and appears to play an important role in AD pathogenesis [52,53]. However, as a consequence, this might implicate a role for EVs in the formation of extracellular $A \beta$ plaques. Mechanistically, the interaction between $\mathrm{A} \beta$ and the surface of the EVs was shown to be mediated by glycosphingolipids [48,54-56] and the cellular prion protein $\left(\mathrm{PrP}^{\mathrm{C}}\right)$ [49] present on the EV membrane. Furthermore, it was shown that the hippocampal administration of EVs isolated from N2a cells [54] or mouse primary neurons [55] in $\mathrm{APP}_{\text {SweInd }}$ mice causes a reduction in total $\mathrm{A} \beta$ levels and the amount of thioflavin-S positive plaques, which was attributed to an EV-associated $A \beta$ uptake by microglia [54]. It is, however, important to note that the administered EVs are derived from healthy sources and that to acquire these positive effects, normally functioning microglia need to be present. The same research group reported that an oral treatment with plant-derived ceramides in $\mathrm{APP}_{\text {SweInd }}$ mice increases the amount of serum and brain tissue-derived EVs that are positive for $\mathrm{A} \beta$ and the neuronal markers neural cell adhesion molecule 1 (NCAM-1) and L1 cell adhesion molecule (L1CAM). This suggests that the treatment increases neuronal EVs harboring $A \beta$ for clearance in vivo. Accordingly, the treatment reduced $A \beta$ pathology and inflammation in the brain, whereas cognitive function as assessed by the Y-maze test was improved [56]. An alternative mechanism of EV-associated clearance of $A \beta$ was reported in a study where an increased degradation of $A \beta$ by microglial cultures upon statin treatment was attributed to the statin-induced release of insulin-degrading enzyme (IDE)-associated EVs [57]. Similarly, altering the release of IDE-containing EVs in $\mathrm{APP}_{\mathrm{Swe}}$-expressing neuroblastoma $\mathrm{N} 2 \mathrm{a}$ affects the degradation of extracellular $A \beta[58]$.

\subsection{The Detrimental Roles of EVs in $A D$}

Although some studies reported beneficial effects of EVs derived from healthy sources in the pathogenesis of $\mathrm{AD}$, their role might be completely different when they are secreted by cells affected by the disease process. Initially, EVs could act as a helpful mechanism to remove accumulating toxic material from an affected cell but, paradoxically, these EVs might subsequently exert detrimental effects. In line with this, EVs were proposed to be a potential escape mechanism for cells to be able to cope with excess amounts of intracellular Tau $[59,60]$. Some data suggest that EV-associated $A \beta$ could be involved in plaque formation. Indeed, the EV marker Flottilin-1 partially colocalized with $A \beta_{1-42}$ in senile plaques of Tg2576 mice [61], whereas both Alix and Flotillin-1 are enriched in amyloid plaques of AD patients compared to age-matched controls [33,62]. Additionally, Tau- and A $\beta$-containing EVs derived from a variety of in vitro and in vivo sources were shown to be taken up by recipient cells in vitro and in vivo, highlighting their potential as vehicles to spread AD-related proteins. In this context, both Tau and A $\beta O$-containing EVs isolated from, respectively, the brain of PS19 Tauopathy mice [63] and AD patients [41] were taken up by neuronal cultures. Subsequently, the A $\beta \mathrm{O}$-containing EVs either release their cargo, causing cytotoxicity, or migrate to further recipient cells [41]. The latter result was reported in other studies and for Tau as well [64,65], supporting the notion that at least part of the EVs that are taken up by the target cell can be re-secreted, thereby achieving a longer distance of action. To this end, the internalized EVs were shown to hijack the secretory endosomal pathway in the recipient neurons [65]. Interestingly, blocking the $\mathrm{EV}$ production, secretion or uptake in neuronal cultures reduces the neuron-to-neuron spread of $\mathrm{A} \beta \mathrm{O}$ and the related toxicity [41]. Furthermore, $\mathrm{A} \beta$-containing EVs isolated from PS1 mutant neurons and the CSF of sporadic, late-onset AD patients are neurotoxic to primary rat cortical neurons, whereby there is a highly significant correlation between the EV $A \beta_{1-42}$ levels and the induced neurotoxicity [29]. In line with this, the in vitro neuronal toxicity of human CSF-derived EVs (defined to be microvesicles) from AD patients is significantly decreased by pre-treatment with anti-A $\beta$ antibodies [66]. Astrocyte-derived EVs (ADEs) isolated from plasma of AD patients exert a similar neurotoxicity in primary rat cortical neurons [67]. This was shown to be due to high levels of several complement proteins in these ADEs that mediate the deposition of the membrane attack complex on the neurons, causing their membrane disruption and the activation of necroptosis $[67,68]$. Furthermore, the addition of microglia-derived EVs (defined to be microvesicles) 
to $A \beta_{1-42}$ aggregates in vitro promoted the formation of small soluble neurotoxic $A \beta_{1-42}$ species, thereby increasing neurotoxicity in cultured primary hippocampal neurons [66].

Tau-containing EVs isolated from the culture medium of either Tau-stimulated microglia [63] or Tau-transduced, human-derived induced pluripotent stem cells (iPSCs) [69] transfer their Tau content to hippocampal neurons after their injection into the hippocampus of WT mice. Intriguingly, besides being taken up and transferring their content, Tau-containing EVs have the potential to mediate the propagation of Tau pathology. Indeed, EVs isolated from in vitro (i.e., N2a cells expressing aggregation-prone Tau [64]) and in vivo (i.e., brain of Tau transgenic rTg4510 mice [70], CSF derived from AD patients $[64,71]$ ) sources can induce Tau aggregation in in vitro systems optimized to assess Tau seeding capacity. Moreover, hippocampal injection of EVs derived from rTg4510 brain induces Tau phosphorylation at the site of injection in Tau transgenic ALZ17 mice [72]. Similar injection setups in WT mice using EVs isolated from either FAD patient-derived [73] or Tau-transduced [74] neuronally differentiated iPSCs revealed the same results. Furthermore, neuron-derived, phosphorylated Tau (p-Tau)-containing EVs from AD and mild cognitive impairment (MCI) patients, but not cognitively normal controls, can propagate Tau pathology upon their injection into the brain of WT mice [75]. Functional studies showing beneficial effects of inhibiting EV secretion add additional weight to the hypothesis that EVs play a detrimental role in the AD disease process. Indeed, pharmacologically inhibiting EV synthesis by the systemic administration of GW4869, an inhibitor of neutral sphingomyelinase 2 (nSMase 2), slows Tau propagation in a mouse model of rapid Tau propagation [63] and reduces the plaque load in 5xFAD mice [50]. Moreover, genetically nSMase 2-deficient 5XFAD mice display a reduction in both plaque burden and Tau phosphorylation, whereas cognitive function is improved [76]. Depleting microglia or microglial Bin1 reduces the EV-associated Tau content in vivo and in vitro and supresses the propagation of Tau pathology in Tauopathy mouse models as well $[63,71]$.

Altogether, these data clearly point towards a detrimental role for EVs in the pathogenesis of AD. However, it is important to add that only a minor part of extracellular $\mathrm{A} \beta(<1 \%)$ and Tau $(<0.2 \%$ to $\sim 2-3 \%)$ is associated with EVs $[33,64,77]$. In line with this, the total levels of $A \beta_{1-40 / 42}$ in EVs isolated from plasma and CSF samples from AD patients were shown to be drastically lower compared to the EV-free fraction of the respective sample types [29]. Nevertheless, the $A \beta_{1-42} / A \beta_{1-40}$ ratio was significantly higher in these EVs, underlining their importance in AD pathogenesis [29]. Additionally, Tau phosphorylated at Threonine 181 (pT181) [78] and oligomeric Tau [64] were suggested to be enriched in human CSF-EVs compared to total CSF in, respectively, mild AD patients and both AD patients and controls. Moreover, EV-associated Tau could induce Tau aggregation in vitro [64] and Tau transduction in vivo [63], whereas naked Tau was unable to achieve these effects. Similar findings were reported for EV-associated A $\beta$ since EVs isolated from PS1 mutant neurons induce neurotoxicity in primary rat cortical neurons to the same extent as EV-depleted medium, although the latter contains about 10-fold more $\mathrm{A} \beta_{1-42}$ compared to the EVs [29].

\section{The Role of EVs in PD}

Next to AD, EVs have also been implicated in the pathogenesis of PD which is characterized by the misfolding and aggregation of $\alpha$-syn followed by its deposition in Lewy bodies and Lewy neurites. Because $\alpha$-syn lacks an ER targeting sequence, it was originally considered as an exclusively intracellular protein. However, this concept was challenged by initial reports showing the presence of extracellular $\alpha$-syn in human CSF $[79,80]$ and plasma [80,81]. Interestingly, studies in human $\alpha$-syn-expressing SH-SY5Y neuroblastoma cells indicated that $\alpha$-syn is continuously secreted via an ER/Golgi-independent mechanism involving the endocytic pathway, whereby at least part of the secreted $\alpha$-syn is associated with EVs [82-84]. Furthermore, it has been shown that $\alpha$-syn can interact with the ESCRT pathway, which ultimately can result in its release in association with EVs $[85,86]$. Several studies collectively indicate that $\alpha$-syn monomers, oligomers and fibrils can be located both in the lumen and on the surface of EVs [82,83,87-92]. However, similar to what has 
been described for $\mathrm{A} \beta$ and Tau, only a minor component of the extracellular $\alpha$-syn associates with EVs $[87,89,90,93-96]$. Nonetheless, several observations point towards an important role for this fraction in the pathogenesis of PD. Intravesicular $\alpha$-syn, present in human $\alpha$-syn-expressing SH-SY5Y neuroblastoma cells, was shown to be more prone to aggregation compared to cytosolic $\alpha$-syn [82]. EVs can also accelerate the aggregation of $\alpha$-syn in vitro, whereby EVs derived from control N2a cells exert the same effect as EVs derived from $\alpha$-syn-overexpressing N2a cells [89]. Of specific relevance, it was reported that EVs isolated from the CSF of patients with PD and dementia with Lewy bodies (DLB), but not control patients, induce $\alpha$-syn aggregation in vitro as well [95]. The addition of EVs isolated from WT mouse brain induces the assembly of recombinant $\alpha$-syn preformed fibrils (PFFs) into higher-order multimers in vitro. In the same timeframe, no multimerization of $\alpha$-syn PFF in the absence of EVs was observed [97]. However, similarly to what was described for A $\beta$ [47], the pre-incubation of $\alpha$-syn PFFs with these EVs neutralized the detrimental effects of $\alpha$-syn PFFs in vitro (i.e., reduced uptake by primary cortical cultures) and in vivo (i.e., inability to induce $\alpha$-syn accumulation after intrastriatal injection in WT mice) [97]. Interestingly, the A53T $\alpha$-syn mutant displays an increased association with EVs, leading to the speculation that pathogenic $\alpha$-syn species may be preferentially sorted into EVs [90]. In line with this, misfolded and oligomeric $\alpha$-syn (i.e., presumably the more toxic form of $\alpha$-syn) were shown to be favorably released with EVs compared to, respectively, native and highly aggregated $\alpha$-syn $[84,98]$.

After their secretion, $\alpha$-syn-containing EVs can be taken up by recipient neurons in vitro, where they induce toxicity $[87,99]$. Of interest, the uptake of EV-associated oligomeric $\alpha$-syn species derived from $\alpha$-syn-expressing H4 neuroglioma [87,94] and SH-SY5Y neuroblastoma [90] cells by the respective naive cells is more efficient compared to that of EV-free $\alpha$-syn. In line with this, sonication of EVs derived from $\alpha$-syn-overexpressing cell lines reduces their internalization and the transfer of $\alpha$-syn to recipient cells, indicating that the EVs need to be intact to efficiently exert these functions $[87,88]$. A functional study investigating the effect of nSMase 2 inhibition in SH-SY5Y cells further underlined the role of EVs in the spreading of $\alpha$-syn between neuronal cells. Indeed, nSMase 2 inhibition results in reduced EV secretion in response to oligomeric $\alpha$-syn. This is accompanied by a reduced transfer of oligomeric $\alpha$-syn to recipient cells [100]. Additionally, in vivo data show that the intrastriatal injection of EVs isolated from human $\alpha$-syn-expressing HEK cells in WT mice resulted in the spreading of the human $\alpha$-syn towards interconnected brain regions [99]. Similarly, $\alpha$-syn neuronal inclusions were detected close to the injection site upon the intracortical administration of CSF-derived EVs from DLB patients in WT mice [92]. Strikingly, the uptake and transfer of $\alpha$-syn-containing EVs has been linked to the prion-like spreading of $\alpha$-syn. EVs obtained from $\alpha$-syn PFFs stimulated primary cortical neurons act as seeds to induce endogenous $\alpha$-syn aggregation in recipient neurons in vitro [101]. Additionally, brain-derived EVs from DLB patients facilitate $\alpha$-syn aggregation in vivo after their intracerebral injection in WT mice [102]. Similar results were seen after the intrastriatal injection of plasma-derived EVs from PD patients [103]. Furthermore, $\alpha$-syn-containing EVs derived from serum of PD patients trigger $\alpha$-syn aggregation, dopaminergic degeneration and motor deficits when administered into the striatum of WT mice [104]. However, EVs isolated from A53T $\alpha$-syn transgenic mouse brain were unable to induce $\alpha$-syn pathology and motor deficits after their intrastriatal injection in WT mice [97].

Although all data described above focus on neuronal-derived EVs, there also appears to be a role for microglia-derived EVs in PD pathogenesis. EVs derived from the plasma of PD patients are internalized by microglia in vitro and in vivo, thereby inducing microglial activation in both setups. Subsequently, BV-2 microglia were shown to secrete $\alpha$-syn-containing EVs which induce $\alpha$-syn aggregation in SH-SY5Y recipient cells [103]. The stimulation of BV-2 microglia cells with $\alpha$-syn results in the release of EVs that are able to induce apoptosis in recipient neurons [105]. Additionally, $\alpha$-syn PFF-stimulated primary microglia secrete $\alpha$-syn oligomer-containing EVs which trigger $\alpha$-syn aggregation in vitro (i.e., in primary cortical neurons) and in vivo (i.e., upon intrastriatal injection in WT mice), leading to the loss of dopaminergic neurons and the occurrence of motor deficits 
in the latter situation [101]. Interestingly, microglia/macrophage-derived CD11b positive EVs are present in the CSF of PD and multiple system atrophy (MSA) patients and are able to induce $\alpha$-syn aggregation in vitro [101]. Together, these data underline the potential of microglia in facilitating the propagation of $\alpha$-syn via EVs.

Several PD-related assets can be linked with EV secretion. Environmental toxins, including certain pesticides and metals, are hypothesized to play a role in the initiation and progression of PD pathology. For example, chronic exposure to high doses of the neurotoxic metal manganese results in manganism which is characterized by many Parkinsonian features [106]. Interestingly, manganese enhances the release of $\alpha$-syn oligomer-containing EVs from $\alpha$-syn-expressing mouse dopaminergic neuronal cells. When these EVs are injected into the striatum of WT mice, they propagate $\alpha$-syn pathology and induce the development of Parkinsonian motor deficits [107]. Additionally, exposure to the pesticide rotenone is associated with developing PD [108]. In this context, it was shown that rotenone is able to induce the release of $\alpha$-syn in association with EVs from WT primary neurons [91]. Collectively, these studies indicate a potential role for $\alpha$-syn-containing EVs connecting environmental triggers and PD. Furthermore, another molecule implicated in PD pathogenesis, namely the lipid peroxidation product 4-hydroxynonenal (HNE), induces the aggregation of endogenous $\alpha$-syn in primary cortical neurons as well as the release of $\alpha$-syn oligomer-containing EVs [99]. An increasing body of evidence links a dysfunction in the endolysosomal-autophagic system, which is increasingly recognized as a central event in the pathophysiology of PD, to EV secretion too [109-111]. Indeed, blocking the fusion of the autophagosome (AP) with the lysosome by Bafilomycin A1 (Baf) treatment in $\alpha$-syn-overexpressing neuronal cell lines increases vesicular $\alpha$-syn release $[84,87,88,92,98]$. This is associated with a higher transmission of $\alpha$-syn to recipient SH-SY5Y cells [88]. Mechanistically, the Baf treatment results in the accumulation of fused AP-MVB compartments in $\alpha$-syn-overexpressing $\mathrm{H} 4$ cells, whereby the EVs secreted by these cells contain several AP markers [92]. Furthermore, blocking autophagy by silencing of autophagy-related gene 5 (ATG5) in $\alpha$-syn-overexpressing Lund human mesencephalic (LUHMES) neuronal cells protects them against the $\alpha$-syn-induced toxicity by increasing the $\alpha$-syn secretion in EVs. As such, the EVs provide a compensatory rescue mechanism for impaired intracellular autophagy [112]. Another association between lysosomal dysfunction and PD is provided by the significant relevance of the lysosomal enzyme glucocerebrosidase (GCase) in PD. Up to 7\% of PD patients carry a mutation in the GBA1 gene [113], whereas PD patients that do not carry a GBA1 mutation also show a significant reduction in lysosomal GCase activity $[114,115]$. Interestingly, the pharmacological inhibition of GCase by conduritol-B epoxide (CBE) in A53T $\alpha$-syn transgenic mice significantly increases brain EV levels and EV-associated oligomeric $\alpha$-syn [116]. A Drosophila model of GCase deficiency shows markedly increased EV numbers in the hemolymph (i.e., the Drosophila equivalent of blood) [117]. Moreover, it is suggested that the excessive EV secretion caused by the GCase deficiency might be responsible for the characteristic presence of protein aggregates in this model, since knocking down components of the ESCRT pathway reduces the accumulation of these protein aggregates [117]. Strikingly, the ratio of EV $\alpha$-syn to total $\alpha$-syn in plasma of PD patients is inversely correlated with GCase enzymatic activity, which again suggests that GCase activity might be linked to the release of EVs [118].

\section{EVs as Potential Biomarkers for AD and PD}

$\mathrm{AD}$ and PD pathology begins multiple years before symptoms arise, hence the diagnosis is made when considerable and irreversible neuronal damage has already occurred [119,120]. Therefore, it is of great importance to identify patients in the earliest stages of the disease, when potential disease-modifying treatments might have the greatest benefit. To this end, biomarkers are of specific interest. Next to diagnosing and monitoring disease, they could be instrumental in evaluating the patients' response to disease-modifying treatments. Interestingly, several studies already indicated that EV-associated proteins might provide a snapshot of the molecular events occurring in the brain of patients with neurodegenerative diseases and thereby serve as a liquid brain biopsy. For example, an analysis of brain tissue-derived EVs revealed that $\mathrm{A} \beta$ and $\mathrm{p}$-Tau are present in 
EVs isolated from AD and DLB patients, whereas in the latter condition they contain $\alpha$-syn as well [102]. Furthermore, EVs isolated from the temporal neocortex of AD patients contain significantly more $\mathrm{A} \beta \mathrm{O}$ compared to EVs from non-neurological control samples [41]. These results indicate that the EV cargo can reflect brain pathology. Another study demonstrating a significant positive correlation between the elevated levels of Tau phosphorylated at Serine 396 (pS396) and A $\beta_{1-42}$ in brain tissue homogenate and brain-derived EVs of AD patients supports this notion [121]. EV-bound A $\beta$ derived from plasma of $\mathrm{AD}$ patients was shown to strongly correlate with brain plaque deposition as assessed by positron emission tomography (PET), whereas this was not the case for total plasma A $\beta$ [122]. These results further demonstrate that brain biomarkers can be detected in the periphery as well. Similarly, several miRNAs were shown to be upregulated in both brain tissue and serum-derived EVs of AD patients, although there was little overall correlation between miRNA expression profiles in brain homogenate, brain tissue-derived EVs and serum-derived EVs [123]. However, the authors suggest that enriching for specific cell type-derived EVs from serum might improve this. Indeed, EVs that are separated from plasma or serum based on their expression of the neuronal surface marker L1CAM are enriched for neuronal proteins compared to the total EV population and control EV subpopulations [124]. Alternatively, NCAM can also be used to enrich for neural-derived EVs (NDEs). Using the latter method, it was shown that the levels of total Tau (t-Tau), pT181 Tau and A $\beta_{1-42}$ in plasma NDEs highly correlate with their respective levels in the CSF [125]. This further underlines the potential of NDEs to reflect pathological changes in the brain [125]. A proteomics analysis of brain tissue-derived EVs revealed that half of the quantified proteins displayed neuron-specific markers and the other half glia-specific markers, whereby the former are enriched in the control group and the latter in the AD group [121]. Another study reported the presence of several central nervous system (CNS) cell type markers (i.e., neurons, microglia, oligodendrocytes and astrocytes) on human brain tissue-derived vesicles that could be explored to capture specific cell type-derived EVs in the periphery [126]. In summary, both the total population and specific cell type enriched EVs in a variety of sources have emerged as potential biomarkers due to their role in the disease process and their ability to carry disease-related molecules.

\subsection{EVs as Biomarkers in $A D$}

Although the majority of studies investigating EV-related biomarkers in AD have been focusing on blood as an easily accessible biofluid, some results were reported in CSF. Both EVs derived from CSF of AD patients and controls have been shown to contain Tau species that are phosphorylated at several sites (i.e., pS262/pS356, pS396/pS404, pT181) [64,78]. The amount of p-Tau in CSF-EVs did not differ between those two groups in one study [64], whereas another report described an increase in the ratio of EV p-Tau to CSF t-Tau specifically in early AD patients [78]. The number of isolectin B4 (IB4) positive particles (defined as myeloid microvesicles) is increased in the CSF of AD patients and MCI patients converting to AD in comparison with stable MCI patients and controls [127]. These levels are associated with hippocampal atrophy and white matter tract damage in AD and MCI patients, respectively [127]. A proteomics analysis on EV separated from CSF samples of AD patients, MCI patients and corresponding controls identified the heat shock $70 \mathrm{kDa}$ protein 1A (HSPA1A), puromycin-sensitive aminopeptidase (NPEPPS) and prostaglandin F2 receptor negative regulator (PTGFRN) as differentially expressed proteins, whereby HSPA1A and NPEPPS are significantly increased in AD patients versus MCI patients and PTGFRN is significantly increased in AD patients versus controls [128]. Additionally, a variety of biomarker candidates have been identified in plasmaor serum-derived NDEs of AD patients. Several of these biomarkers have promising abilities to distinguish patients from controls, whereby some of them might aid disease staging and even predict disease development from a preclinical stage. These results are summarized in Table 1. As an indication of the diagnostic ability of the identified biomarkers, the area under the receiver operating curve (ROC) is included when available. Alternatively, the sensitivity, specificity or $p$-value are mentioned. 
Table 1. Overview of extracellular vesicle (EV)-associated biomarkers in Alzheimer's disease (AD).

\begin{tabular}{|c|c|c|c|c|c|c|c|c|c|c|c|}
\hline & & & & EV Q & & & & & vs. ctrl & & \\
\hline Source & Cohort & $\begin{array}{l}\text { EV Isolation } \\
\text { Method }\end{array}$ & NTA & TEM & $\begin{array}{c}\text { EV } \\
\text { Markers }\end{array}$ & Category & Biomarker & Result & Statistics & $\begin{array}{c}\text { Additional } \\
\text { Potential }\end{array}$ & Ref \\
\hline \multirow{4}{*}{ CSF } & $\begin{array}{l}\text { AD: } 10 \\
\text { Ctrl: } 10\end{array}$ & $\begin{array}{c}\text { Differential } \\
\text { centrifugation }\end{array}$ & $\mathrm{x}$ & $\mathrm{x}$ & + & \multirow{3}{*}{$\begin{array}{c}\text { Neurotoxic } \\
\text { protein }\end{array}$} & p-Tau & $=$ & ns & & [64] \\
\hline & AD: 21 & Ultracentrifugation + & & & + & & $\begin{array}{c}\text { Ratio EV pT181 } \\
\text { Tau/EV t-Tau }\end{array}$ & $\uparrow$ & $p=0.04$ & \multirow{2}{*}{ Prognostic } & \multirow{2}{*}[78]{} \\
\hline & Ctrl: 9 & $\begin{array}{l}\text { sucrose gradient } \\
\text { fractionation }\end{array}$ & & & & & $\begin{array}{c}\text { Ratio EV pT181 } \\
\text { Tau/CSF pT181 Tau }\end{array}$ & & $p=0.002$ & & \\
\hline & $\begin{array}{l}\text { AD: } 7 \\
\text { ctrl: } 7\end{array}$ & $\begin{array}{l}\text { Total Exosome } \\
\text { isolation kit }\end{array}$ & & & & \multirow{7}{*}{ miRNA } & miR-193b & $\downarrow$ & $p<0.05$ & & [129] \\
\hline \multirow{7}{*}{ Serum } & $\begin{array}{l}\text { AD: } 22 \\
\text { Ctrl: } 16\end{array}$ & ExoQuick & $\mathrm{x}$ & & + & & miR-223 & $\downarrow$ & $\mathrm{AUC}=0.875$ & & [130] \\
\hline & $\begin{array}{l}\text { AD: } 39 \\
\text { MCI: } 11 \\
\text { Ctrl: } 59\end{array}$ & $\begin{array}{c}\text { Plasma/Serum } \\
\text { exosome } \\
\text { isolation kit }\end{array}$ & & & & & $\begin{array}{l}\text { miRNA signature } \\
\text { (16 miRNAs) }\end{array}$ & $\neq$ & $\begin{array}{l}\text { Sens: } 87 \% \\
\text { Spec: } 77 \%\end{array}$ & & [131] \\
\hline & $\begin{array}{l}\text { AD: } 51 \\
\text { MCI: } 43 \\
\text { ctrl: ? }\end{array}$ & $\begin{array}{l}\text { Total Exosome } \\
\text { isolation kit }\end{array}$ & & & & & miR-193b & $\downarrow$ & $p<0.05$ & Prognostic & [129] \\
\hline & \multirow{3}{*}{$\begin{array}{l}\text { AD: } 107 \\
\text { MCI: } 101 \\
\text { Ctrl: ? }\end{array}$} & \multirow{3}{*}{$\begin{array}{l}\text { Total Exosome } \\
\text { isolation kit }\end{array}$} & \multirow{3}{*}{$\mathrm{x}$} & & \multirow{3}{*}{+} & & miR-135a & \multirow{2}{*}{$\uparrow$} & $\begin{array}{l}\text { Sens: } 95 \% \\
\text { Spec: } 96 \%\end{array}$ & & \multirow{3}{*}{132} \\
\hline & & & & & & & miR-384 & & $\begin{array}{l}\text { Sens: } 97 \% \\
\text { Spec: } 99 \%\end{array}$ & \multirow{2}{*}{ Prognostic } & \\
\hline & & & & & & & miR-193b & $\downarrow$ & $\begin{array}{l}\text { Sens: } 94 \% \\
\text { Spec: } 86 \%\end{array}$ & & \\
\hline & $\begin{array}{l}\text { AD: } 25 \\
\text { Ctrl: } 17\end{array}$ & $\begin{array}{c}\text { ExoQuick + } \\
\text { immunoprecipitation } \\
\text { with L1CAM }\end{array}$ & & & + & $\begin{array}{l}\text { Synaptic } \\
\text { protein }\end{array}$ & SNAP25 & $\downarrow$ & $\mathrm{AUC}=0.826$ & & [133] \\
\hline
\end{tabular}


Table 1. Cont

\begin{tabular}{|c|c|c|c|c|c|c|c|c|c|c|c|}
\hline & & & & EV QC & & & & & D vs. ctrl & & \\
\hline Source & Cohort & EV Isolation Method & NTA & TEM & $\begin{array}{c}\text { EV } \\
\text { Markers }\end{array}$ & Category & Biomarker & Result & Statistics & $\begin{array}{c}\text { Additional } \\
\text { Potential }\end{array}$ & Ref \\
\hline \multirow{3}{*}{ Plasma/serum } & \multirow{3}{*}{$\begin{array}{l}\text { AD: } 57 \\
\text { Ctrl: } 57 \\
\text { FU AD: } 24\end{array}$} & & \multirow{3}{*}{$\mathrm{x}$} & & \multirow{3}{*}{+} & \multirow{3}{*}{$\begin{array}{l}\text { Neurotoxic } \\
\text { proteins }\end{array}$} & t-Tau & $=$ & & & \multirow{3}{*}{134} \\
\hline & & & & & & & $\begin{array}{l}\text { pS396 Tau } \\
\text { pT181 Tau }\end{array}$ & \multirow{2}{*}{$\uparrow$} & \multirow{2}{*}{$\mathrm{AUC}=0.999$} & Preclinical & \\
\hline & & & & & & & $A \beta 1-42$ & & & $\begin{array}{l}\text { Preclinical, } \\
\text { prognostic }\end{array}$ & \\
\hline \multirow{13}{*}{ Plasma } & \multirow{4}{*}{$\begin{array}{l}\text { AD 1: } 120 \\
\text { Ctrl 1: } 222 \\
\text { AD 2: } 35 \\
\text { Ctrl 2: } 29\end{array}$} & & \multirow{4}{*}{$\mathrm{x}$} & \multirow{4}{*}{$\mathrm{x}$} & \multirow{4}{*}{$+;-$} & \multirow{2}{*}{$\begin{array}{l}\text { Neurotoxic } \\
\text { proteins }\end{array}$} & $\begin{array}{c}\mathrm{A} \beta 1-42 \\
\mathrm{t}-\mathrm{Tau}\end{array}$ & $=$ & $\begin{array}{l}\text { Optimal model } \\
\text { cohort 1: } \\
\text { aUCtrain }-0896\end{array}$ & & \multirow{4}{*}{135} \\
\hline & & & & & & & $\begin{array}{c}\text { pT181 Tau } \\
\text { pT231 }\end{array}$ & \multirow{3}{*}{\multicolumn{2}{|c|}{$\begin{array}{c}\text { AUC } C^{\text {train }}=0.896 ; \\
\text { AUC }^{\text {test }}=0.8 \\
\text { Optimal model } \\
\text { cohort 2: } \\
\text { AUC } C^{\text {train }}=0.989 ; \\
\text { AUC }^{\text {test }}=0.767\end{array}$}} & \multirow{3}{*}{ Preclinical } & \\
\hline & & & & & & \multirow{2}{*}{$\begin{array}{l}\text { Insulin } \\
\text { signaling }\end{array}$} & IRS-1-pS312 & & & & \\
\hline & & & & & & & IRS-1-pTyr & & & & \\
\hline & \multirow{5}{*}{$\begin{array}{l}\text { AD: } 10 \\
\text { ADC: } 20 \\
\text { MCI: } 20 \\
\text { Ctrl: } 10\end{array}$} & ExoQuick + & \multirow{5}{*}{$\mathrm{x}$} & \multirow{5}{*}{$\mathrm{x}$} & \multirow{5}{*}{+} & \multirow{3}{*}{$\begin{array}{l}\text { Neurotoxic } \\
\text { proteins }\end{array}$} & pT181 Tau & \multirow{3}{*}{$\uparrow$} & $\mathrm{AUC}=1$ & \multirow{5}{*}{ Prognostic } & \multirow{5}{*}{ [75] } \\
\hline & & immunoprecipitation & & & & & pS396 Tau & & $\mathrm{AUC}=0.98$ & & \\
\hline & & & & & & & $\mathrm{A} \beta_{1-42}$ & & $\mathrm{AUC}=0.98$ & & \\
\hline & & & & & & $\begin{array}{l}\text { Synaptic } \\
\text { protein }\end{array}$ & Neurogranin & \multirow[t]{2}{*}{$\downarrow$} & $\mathrm{AUC}=1$ & & \\
\hline & & & & & & Survival factor & REST & & $\mathrm{AUC}=1$ & & \\
\hline & $\begin{array}{l}\text { AD: } 20 \\
\text { MCI: } 10 \\
\text { Ctrl: } 10\end{array}$ & & \multirow[t]{4}{*}{$\mathrm{x}$} & & + & $\begin{array}{c}\text { Neurotoxic } \\
\text { proteins }\end{array}$ & $\begin{array}{c}\text { t-Tau } \\
\text { pT181 Tau }\end{array}$ & $=$ & ns & & [136] \\
\hline & & & & & \multirow{3}{*}{+} & \multirow{3}{*}{$\begin{array}{l}\text { Insulin } \\
\text { signaling }\end{array}$} & IRS-1-pS312 & $\uparrow$ & AUC $=0.932$ & \multirow[b]{3}{*}{ Preclinical } & \\
\hline & AD: 26 & & & & & & IRS-1-pTyr & $\downarrow$ & $\mathrm{AUC}=1$ & & \\
\hline & FU AD: 22 & & & & & & $\begin{array}{c}\text { Ratio } \\
\text { IRS-1-pS312/IRS-1 } \\
\text { pTyr }\end{array}$ & $\uparrow$ & $\mathrm{AUC}=1$ & & [137] \\
\hline
\end{tabular}


Table 1. Cont

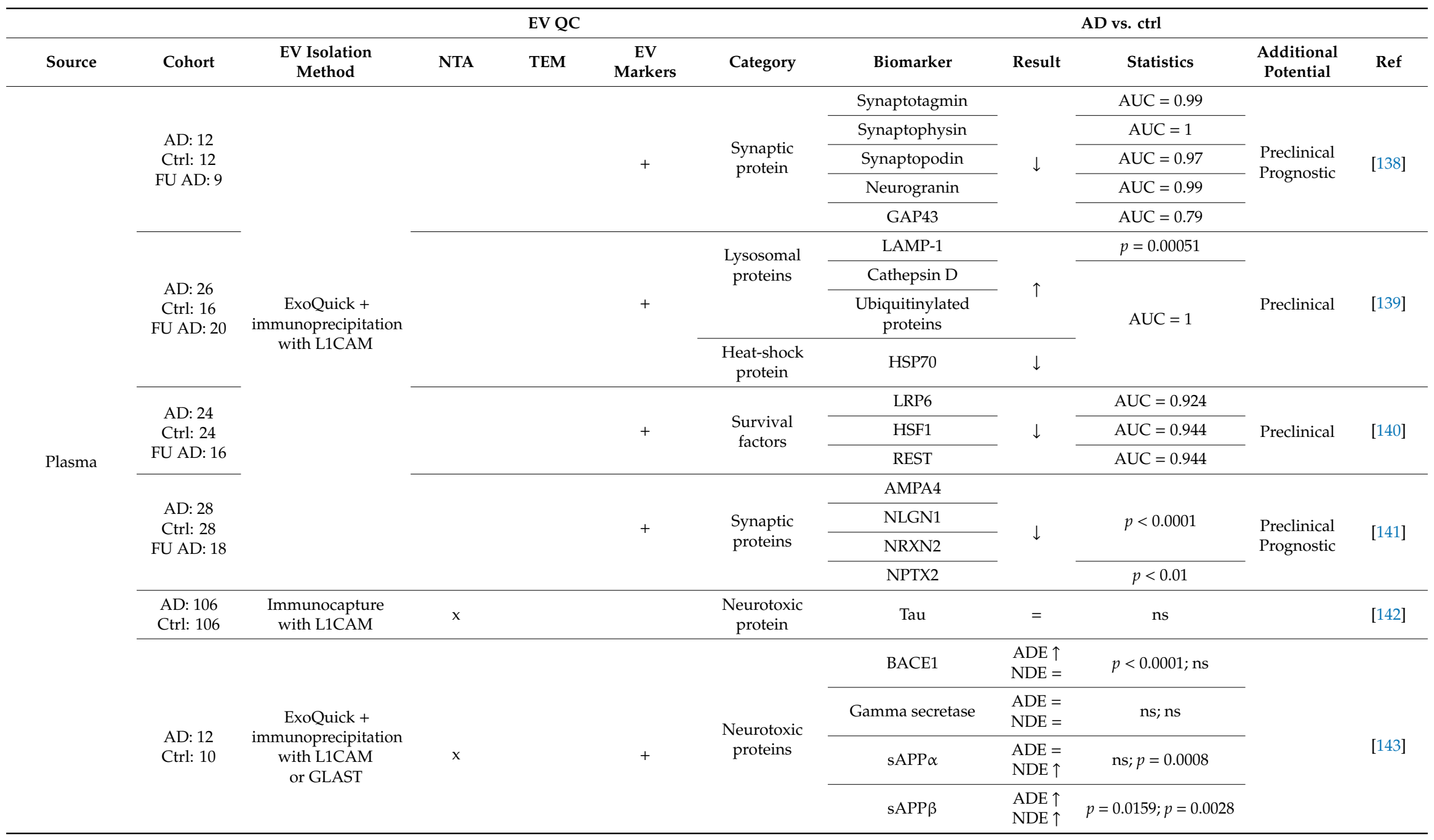


Table 1. Cont

\begin{tabular}{|c|c|c|c|c|c|c|c|c|c|c|c|}
\hline & & & & EV QC & & & & & D vs. ctrl & & \\
\hline Source & Cohort & EV Isolation Method & NTA & TEM & $\begin{array}{c}\text { EV } \\
\text { Markers }\end{array}$ & Category & Biomarker & Result & Statistics & $\begin{array}{c}\text { Additional } \\
\text { Potential }\end{array}$ & Ref \\
\hline \multirow{15}{*}{ Plasma } & \multirow{7}{*}{$\begin{array}{l}\text { AD: } 28 \\
\text { Ctrl: } 28 \\
\text { FU AD: } 16\end{array}$} & \multirow{7}{*}{$\begin{array}{c}\text { ExoQuick + } \\
\text { immunoprecipitation } \\
\text { with GLAST }\end{array}$} & \multirow{7}{*}{$x$} & \multirow{7}{*}{$x$} & \multirow{7}{*}{$+;-$} & & $\begin{array}{c}\text { pT181 and pS396 } \\
\text { Tau }\end{array}$ & $\begin{array}{l}\mathrm{ADE}= \\
\mathrm{NDE} \uparrow\end{array}$ & ns; - & & \\
\hline & & & & & & & $\mathrm{A} \beta 1-42$ & $\begin{array}{l}\mathrm{ADE} \downarrow \\
\mathrm{NDE} \uparrow\end{array}$ & $p<0.05$ & & \\
\hline & & & & & & Neural protein & Septin-8 & $\begin{array}{l}\mathrm{ADE} \downarrow \\
\mathrm{NDE}=\end{array}$ & $p<0.0001 ; \mathrm{ns}$ & & \\
\hline & & & & & & $\begin{array}{l}\text { Inflammatory } \\
\text { cytokines }\end{array}$ & IL-6, TNF- $\alpha$, IL-1 $\beta$ & \multirow{3}{*}{$\uparrow$} & $\begin{array}{l}p<0.001 \\
p<0.01 \\
p<0.001\end{array}$ & & \multirow{4}{*}[67,68]{} \\
\hline & & & & & & \multirow{3}{*}{$\begin{array}{l}\text { Complement } \\
\text { proteins }\end{array}$} & $\begin{array}{l}\text { C1q, C3b, C3d, C4b, } \\
\text { C5b-C9 TCC }\end{array}$ & & \multirow{2}{*}{$p<0.0001$} & \multirow{3}{*}{$\begin{array}{l} \\
\text { Preclinical, } \\
\text { prognostic } \\
\end{array}$} & \\
\hline & & & & & & & $\begin{array}{c}\text { Factor B, Factor D, } \\
\text { Fragment Bb } \\
\text { CR1, CD46 }\end{array}$ & & & & \\
\hline & & & & & & & CD59, DAF & $\downarrow$ & $p<0.0001$ & & \\
\hline & \multirow{4}{*}{$\begin{array}{l}\text { AD: } 24 \\
\text { Ctrl: } 24 \\
\text { FU AD: } 15\end{array}$} & \multirow{4}{*}{$\begin{array}{c}\text { ExoQuick + } \\
\text { immunoprecipitation } \\
\text { with } \\
\text { CSPG4 and PDGFRa }\end{array}$} & \multirow{4}{*}{$x$} & & \multirow{4}{*}{+} & \multirow{4}{*}{$\begin{array}{l}\text { Neurotrophic } \\
\text { factors }\end{array}$} & HGF & \multirow{4}{*}{$\downarrow$} & & \multirow{4}{*}{ Preclinical } & \multirow{4}{*}{ [144] } \\
\hline & & & & & & & FGF2 & & $p<0.0001$ & & \\
\hline & & & & & & & IGF1 & & & & \\
\hline & & & & & & & FGF13 & & $p<0.01$ & & \\
\hline & \multirow{3}{*}{$\begin{array}{l}\text { AD: } 101 \\
\text { MCI: } 96 \\
\text { Ctrl: } 101\end{array}$} & \multirow{3}{*}{$\begin{array}{c}\text { ExoQuick + } \\
\text { immunoprecipitation } \\
\text { with NCAM }\end{array}$} & & \multirow{3}{*}{$\mathrm{x}$} & \multirow{3}{*}{+} & \multirow{3}{*}{$\begin{array}{l}\text { Neurotoxic } \\
\text { proteins }\end{array}$} & $\mathrm{t}$-Tau & \multirow{3}{*}{$\uparrow$} & $\begin{aligned} \mathrm{AUC}^{\text {train }} & =0.87 ; \\
\mathrm{AUC}^{\text {test }} & =0.89\end{aligned}$ & \multirow{3}{*}{$\begin{array}{l}\text { Preclinical } \\
\text { Prognostic }\end{array}$} & \multirow{3}{*}{ [125] } \\
\hline & & & & & & & pT181 Tau & & $\begin{aligned} \mathrm{AUC}^{\text {train }} & =0.89 ; \\
\mathrm{AUC}^{\text {test }} & =0.88\end{aligned}$ & & \\
\hline & & & & & & & $\mathrm{A} \beta 1-42$ & & $\begin{array}{l}\text { AUC train and } \\
\text { AUC }^{\text {test }}=0.93\end{array}$ & & \\
\hline & $\begin{array}{l}\text { AD: } 35 \\
\text { Ctrl: } 35\end{array}$ & $\begin{array}{c}\text { Differential } \\
\text { centrifugation }\end{array}$ & & & + & & miRNA signature & $\neq$ & $\mathrm{AUC}=0.919$ & & [145] \\
\hline
\end{tabular}


Table 1. Cont

\begin{tabular}{|c|c|c|c|c|c|c|c|c|c|c|c|}
\hline & & & & EV QC & & & & & s. ctrl & & \\
\hline Source & Cohort & EV Isolation Method & NTA & TEM & $\begin{array}{c}\text { EV } \\
\text { Markers }\end{array}$ & Category & Biomarker & Result & Statistics & $\begin{array}{c}\text { Additional } \\
\text { Potential }\end{array}$ & Ref \\
\hline \multirow{3}{*}{ Plasma } & $\begin{array}{l}\text { AD: } 31 \\
\text { MCI: } 16 \\
\text { Ctrl: } 16\end{array}$ & \multirow{3}{*}{$\begin{array}{c}\text { ExoQuick + } \\
\text { immunoprecipitation } \\
\text { with L1CAM }\end{array}$} & & & + & \multirow{3}{*}{ miRNA } & $\begin{array}{l}\mathrm{miR}-212 \\
\mathrm{miR}-132\end{array}$ & $\downarrow$ & $\begin{array}{l}\text { AUC: } 0.77 \\
\text { AUC: } 0.84\end{array}$ & & [146] \\
\hline & & & & & & & miR-100-3p & $\downarrow$ & $p=0.008$ & \multirow{2}{*}{\multicolumn{2}{|c|}{ [147] }} \\
\hline & $\begin{array}{l}\text { AD: } 40 \\
\text { Ctrl: } 40\end{array}$ & & & $x$ & + & & $\begin{array}{l}\operatorname{miR}-23 a-3 p \\
\text { miR-223-3p } \\
\text { miR-190a-5p }\end{array}$ & $\uparrow$ & $\begin{array}{l}p=0.008 \\
p=0.016 \\
p=0.003\end{array}$ & & \\
\hline
\end{tabular}

This table only discusses results obtained in Alzheimer's disease (AD) patients, patients with mild cognitive impairment (MCI) and controls (ctrl). Follow-up (FU) AD patients provided samples at two time-points: first when cognitively intact and later when diagnosed with AD. ADC patients are MCI patients who are converting to AD. For reference [135], cohort 1 consists of longitudinal samples collected from AD patients prior to symptom onset and respective controls, whereas cohort 2 consists of longitudinal samples of clinical $\mathrm{AD}$ patients and respective controls. In the extracellular vesicle (EV) markers column, the + symbol indicates the assessment of typical EV markers whereas the-symbol indicates the assessment of non-EV markers. For statistics, preferably the area under the receiver operating curve (AUC) or alternatively the sensitivity (sens) and specificity (spec) or $p$-value are indicated. Preclinical biomarkers have the potential to identify patients at an early disease stage before the occurrence of clinical symptoms. Prognostic biomarkers have the potential to differentiate between different stages of $\mathrm{AD}$ and follow-up disease progression. Abbreviations: QC, quality control; NTA, nanoparticle tracking analysis; TEM: transmission electron microscopy; CSF, cerebrospinal fluid; p-Tau, phosphorylated Tau; t-Tau, total Tau; SNAP25, synaptosomal-associated-protein 25; A $\beta$, amyloid beta; REST, repressor element 1-silencing transcription factor; IRS-1, insulin receptor substrate-1; GAP43, growth-associated protein 43; LAMP-1, lysosome-associated membrane protein 1; HSP70, heat-shock protein 70; 1-silencing transcription factor; IRS-1, insulin receptor substrate-1; GAP43, growth-associated protein 43; LAMP-1, lysosome-associated membrane protein 1; HSP70, heat-shock protein 70;
LRP6, lipoprotein receptor-related protein 6; HSF1, heat-shock factor-1; AMPA4, GluA4-containing glutamate; NLGN1, neuroligin 1; NRXN2, neurexin 2a; NPTX2, neuronal pentraxin 2; LRP6, lipoprotein receptor-related protein 6; HSF1, heat-shock factor-1; AMPA4, GluA4-containing glutamate; NLGN1, neuroligin 1; NRXN2, neurexin 2a; NPTX2, neuronal pentraxin 2;
BACE1, $\beta$-site APP cleaving enzyme-1; sAPP $\alpha$, soluble APP $\alpha$; sAPP $\beta$, soluble APP $\beta$; IL-6, interleukin 6; TNF- $\alpha$, tumor necrosis factor $\alpha$; IL-1 $\beta$, interleukin $1 \beta$; TCC, terminal complement BACE1, $\beta$-site APP cleaving enzyme-1; sAPP $\alpha$, soluble APP $\alpha$; sAPP $\beta$, soluble APP $\beta$; IL-6, interleukin 6; TNF- $\alpha$, tumor necrosis factor $\alpha$; IL-1 $\beta$, interleukin $1 \beta$; TCC, terminal complement
complex; CR1, complement receptor type 1; DAF, decay-accelerating factor; HGF, hepatocyte growth factor; FGF, fibroblast growth factor; IGF1, insulin-like growth factor 1; L1CAM, L1 cell adhesion molecule; NCAM, neural cell adhesion molecule; GLAST, glutamine aspartate transporter; CSPG4, chondroitin sulfate proteoglycan 4; PDGFR $\alpha$, platelet growth factor receptor $\alpha$; $\mathrm{ADE}$, astrocyte-derived EV; NDE, neural-derived EV. 
NDEs derived from plasma or serum from AD patients contain increased levels of pT181 Tau, pS396 Tau and $A \beta_{1-42}$ compared to controls $[75,125,134,143]$. Strikingly, this is already the case for up to ten years before their diagnosis when these patients were still cognitively normal [134]. Moreover, the levels of those three markers are increased in $\mathrm{MCI}$ patients converting to $\mathrm{AD}$ in comparison with stable MCI patients as well [75]. Therefore, this set of biomarkers has the potential to distinguish different stages of $\mathrm{AD}$ whereby both persons at risk at their preclinical stage and MCI patients that are most likely to progress to AD can be identified. Additionally, the plasma NDE levels of pT181 Tau and A $\beta_{1-42}$ highly correlate with their levels in the CSF, further underlining the potential of NDEs to reflect pathological changes in the brain [125]. A large case-control study analyzed several of these biomarker candidates in NDEs separated from longitudinal plasma samples collected prior to AD disease onset which occurred on average four years after collecting the earliest preclinical sample. NDEs from future AD patients contained longitudinally elevated mean levels of pT181 Tau and pT231 Tau in comparison with controls, whereas t-Tau and, surprisingly, A $\beta_{1-42}$ remained unaltered. Furthermore, the NDE diameter was increased but no differences in NDE concentration could be observed. Combining several repeated measures in a prediction model could predict AD with high specificity [135]. Another study did not report differences between the pT181 Tau levels in NDEs from patients with AD, MCI and controls [136]. The plasma NDE levels of pT181 Tau and A $\beta_{1-42}$ in AD patients also do not correlate with cognitive decline [138], whereas the mean longitudinal plasma NDE levels of pT181 Tau in preclinical AD patients were associated with cognitive performance [135]. Total Tau levels in plasma-derived NDEs were shown to be indifferent between AD patients and controls, but significantly upregulated in PD patients where they correlate with disease severity [142]. In contrast, increased levels of $t$-Tau have also been reported in plasma-derived NDEs from AD patients [125]. Differences in the methods to enrich for NDEs and to assess the $t$-Tau levels might provide an explanation for these discrepancies. Next to A $\beta$, other products of the APP processing pathway (i.e., $\mathrm{SAPP} \alpha$ and $\mathrm{SAPP} \beta$ ) are also increased in plasma NDEs from AD patients compared to controls [143]. Serum-derived NDEs isolated from older individuals with age-related cognitive decline milder than MCI or dementia also show higher pT231 Tau, pT181 Tau and t-Tau in comparison with age-matched cognitively stable individuals [148].

Alterations in insulin signaling, such as dysregulated phosphorylation of the insulin receptor substrate-1 (IRS-1), which can trigger insulin resistance, have been linked to the pathogenesis of AD [137,149]. This is reflected in plasma-derived NDEs of AD patients since the levels of IRS-1-pS312 and IRS-1-pTyr are increased and decreased, respectively, compared to controls [137]. Moreover, these altered levels correlate with brain atrophy in the AD patients, again supporting that peripheral EV biomarkers can reflect changes in the AD brain [150]. Furthermore, the insulin resistance index (i.e., the ratio of IRS-1-pS312 to IRS-1-pTyr) is significantly increased in the AD condition. Strikingly, these differences already plateaued in preclinical patients up to ten years before their AD diagnosis was made [137]. In line with these data, the mean IRS-1-pS312 levels amongst longitudinal plasma-derived NDEs of preclinical AD patients were significantly elevated in comparison with controls and were associated with worse cognitive performance. However, in this sample set, the IRS-1-pTyr levels were significantly increased in preclinical AD patients as well [135]. Importantly, the levels of several insulin signaling mediators in serum-derived NDEs were shown to be associated with a longitudinal, prospective change in cognitive performance in a cohort of individuals with and without age-related cognitive decline [148]. The plasma NDE levels of several synaptic proteins and transcription factors mediating neuronal protection are significantly decreased in multiple $\mathrm{AD}$ stages (preclinical $\mathrm{AD}$ patients, $\mathrm{MCI}$ patients converting to $\mathrm{AD}, \mathrm{AD}$ patients) compared to controls and stable MCI patients [75,138-141]. In contrast, the levels of multiple lysosomal proteins are significantly increased in the preclinical AD group compared to controls [139]. At the stage of diagnosis one to ten years later, the levels of almost all synaptic proteins declined even further, whereas they remained constant for most lysosomal proteins and the transcription factors [138-141]. The detailed information of all investigated biomarkers of each category can be found in Table 1 . These data suggest 
the identification of multiple promising preclinical biomarker candidates, whereas several synaptic proteins additionally hold promise as prognostic biomarkers. Furthermore, the altered levels of several biomarkers in NDEs correlate with the Mini Mental State Examination (MMSE) score of AD patients, suggesting that they could be used to follow the progression of cognitive decline. This is the case for the synaptosomal-associated-protein 25 (SNAP25) in serum NDEs and the synaptic proteins synaptopodin, synaptophysin, GluA4-containing glutamate (AMPA4) and neuroligin 1 (NLGN1) in plasma-derived NDEs, of which the levels are decreased in AD patients compared to controls [133,138,141]. A similar positive correlation with the MMSE score was shown for the decreased levels of miR-223 in EVs isolated from serum of dementia patients, including both AD and vascular dementia cases [130]. Since plasma and serum-derived EVs have been shown to be enriched in miRNAs compared to cell-free plasma and serum, the miRNA profile of EVs has also attracted considerable attention as a potential biomarker [151]. The levels of miR-193b are lower in EVs derived from serum of AD patients compared to MCI patients, which in turn show decreased levels compared to controls [129,132]. Conversely, miR-384 show the inverse pattern, whereas miR-135a is equally increased in MCI and AD patients [132]. Both in serum- [131] and plasma- [145] derived EVs of AD patients, panels of differentially expressed miRNAs were identified that could differentiate AD patients from controls. In plasma NDEs, miR-212 and miR-132 are decreased in AD patients compared to controls [146]. Furthermore, decreased miR-100-3p levels and increased miR-23a-3p, miR-223-3p and miR-190a-5p levels were reported in plasma NDEs of $\mathrm{AD}$ patients in comparison with controls [147].

Next to NDEs, ADEs, isolated using an antibody against the glutamine aspartate transporter (GLAST), have also been investigated. It has been shown that the total number of plasma ADEs is significantly lower than the number of plasma NDEs in AD patients and controls. Nonetheless, the plasma ADEs contain significantly higher levels of a number of proteins (i.e., BACE1, $\gamma$-secretase, sAPP $\alpha$, sAPP $\beta, \mathrm{pT} 181, \mathrm{pS} 396$ and A $\beta_{1-42}$ ) compared to NDEs [143]. From this set of proteins, the levels of BACE1 and sAPP $\alpha$ are significantly higher, whereas the levels of $A \beta_{1-42}$ and the neural protein septin-8 are significantly lower in ADEs of AD patients compared to controls [143]. As a side note, the authors mention that these significant but moderate differences might be less useful to diagnose AD. However, they might provide a way to monitor the effect of, for example, drugs that aim to inhibit BACE1 [143]. Furthermore, a variety of complement proteins are significantly upregulated in plasma ADEs of $\mathrm{AD}$ patients at the dementia stage, but not yet in the preclinical $\mathrm{AD}$ phase. In contrast, the levels of the complement regulatory proteins CD59 and decay-accelerating factor (DAF) are already decreased at the preclinical phase and further decline as the disease progresses [68]. Since complement regulatory proteins normally prevent excessive complement activation, their decrease in the preclinical phase might be the cause of complement activation in astrocytes later on [68]. Another subtype of specific EVs that has been isolated are EVs derived from chondroitin sulfate proteoglycan (CSPG) 4 type neural precursor cells [144]. These EVs are less abundant in comparison with ADEs and NDEs in plasma of AD patients and controls, but they contain significantly higher levels of several neurotrophic factors whereby the levels are lower in both preclinical and later stage AD patients compared to controls [144]. However, because of the low abundance of CSPG4 EVs, their biomarker potential will likely be quite limited [144].

Interestingly, EVs have already been used for treatment follow-up in clinical trials. One trial demonstrated improved cognition after a daily subcutaneous treatment with growth hormone-releasing hormone (GHRH) over 20 weeks in MCI patients [152]. Plasma NDEs derived from those patients contain significantly higher levels of $A \beta_{1-42}$ and significantly lower levels of several synaptic proteins (i.e., neurogranin, synaptophysin, synaptotagmin, synaptopodin) compared to controls. However, the levels of none of these biomarkers were significantly altered due to the GHRH treatment [153]. In the Study of Nasal Insulin in the Fight Against Forgetfulness (SNIFF120) clinical trial, AD and MCI patients that were treated daily with an intranasal dose of 20 international units (IU) of insulin for four months showed improved cognition [154]. This outcome correlates positively with changes in IRS-1-pS312 and IRS-1-pTyr in plasma NDEs of these patients, although no significant 
difference in the levels of these markers between baseline and the study endpoint were detected. In the future, these results could be helpful to determine which patients are most likely to benefit from the treatment [155].

\subsection{EVs as Biomarkers in $P D$}

In PD patients, the total level of EVs was reported to be unchanged [156] or lowered [157] in serum, unchanged in plasma [118] and increased in CSF [95]. Next to EV levels, a growing number of studies found several promising candidate biomarkers associated with these EVs in a variety of biological sources. These results are summarized in Table 2. In CSF samples, the $\alpha$-syn EV levels are lower in early stage PD patients compared to healthy controls. In contrast, no differences could be detected in more advanced stage PD patients compared to neurological controls (i.e., polyneuropathy and progressive supranuclear palsy (PSP) patients). However, compared to the latter three groups, EVs derived from CSF of DLB patients show decreased levels of $\alpha$-syn which correlate with the patients' severity of cognitive impairment as assessed by the MMSE scores [95]. Another study specifically investigated the microglia/macrophage-derived, CD11b positive EVs in CSF samples of PD, MSA and control patients. Although the total number of EVs and the fibrillary $\alpha$-syn levels do not differ, both the total and oligomeric $\alpha$-syn levels are increased in PD and MSA patients [101]. In plasma, the $\alpha$-syn levels in both the total pool $[103,118]$ and the L1CAM positive $[158,159]$ pool of EVs are significantly elevated in PD patients compared to controls. More specifically, one study reported that the total, monomeric and oligomeric $\alpha$-syn levels in these plasma EVs are increased, whereas no differences were detected in fibrillar $\alpha$-syn [103]. Similarly, serum EVs isolated from PD patients were shown to contain elevated levels of total, monomeric, oligomeric and pSer129 $\alpha$-syn [104]. Of note, these EVs also contain higher levels of the inflammatory cytokines tumor necrosis factor alpha (TNF- $\alpha$ ) and interleukin 1 beta (IL-1 $\beta$ ) [104]. Furthermore, total $\alpha$-syn levels in L1CAM positive serum EVs are elevated approximately two-fold in conditions with Lewy body pathology compared to MSA and unrelated neurodegenerative diseases [160]. As an important readout to monitor and predict disease progression, it was shown that $\alpha$-syn in plasma L1CAM positive EVs correlates with disease severity as assessed by the Unified Parkinson's Disease Rating Scale (UPDRS) score [158]. However, another report did not identify this association [159]. Additionally, no correlation between $\alpha$-syn in serum-derived, L1CAM positive EVs and the UPDRS or Montreal cognitive assessment (MoCa) score was found [160]. In the total EV pool in plasma of PD patients, a negative correlation was found between the ratio of EV $\alpha$-syn to plasma $\alpha$-syn and disease severity, as assessed by the Hoehn and Yahr (H\&Y) score [118]. 
Table 2. Overview of extracellular vesicle (EV)-associated biomarkers in Parkinson's disease (PD).

\begin{tabular}{|c|c|c|c|c|c|c|c|c|c|}
\hline \multirow[b]{2}{*}{ Source } & \multirow[b]{2}{*}{ Cohort } & \multirow[b]{2}{*}{ EV Isolation Method } & \multicolumn{3}{|c|}{ EV QC } & \multicolumn{4}{|c|}{ PD vs. ctrl } \\
\hline & & & NTA & TEM & $\begin{array}{c}\text { EV } \\
\text { Markers }\end{array}$ & Biomarker & Result & Statistics & Reference \\
\hline \multirow{4}{*}{ CSF } & $\begin{array}{l}\text { PD: } 76 \\
\text { Ctrl: } 58\end{array}$ & $\begin{array}{c}\text { Differential } \\
\text { centrifugation }\end{array}$ & $\mathrm{x}$ & $\mathrm{x}$ & $+;-$ & $\alpha$-syn & $\downarrow$ & $p<0.05$ & [95] \\
\hline & \multirow{3}{*}{$\begin{array}{l}\text { PD: } 9 \\
\text { Ctrl: } 9\end{array}$} & \multirow{3}{*}{ CD11b immunocapture } & & & & $\alpha$-syn & $\uparrow$ & $p<0.05$ & \multirow{3}{*}{ [101] } \\
\hline & & & & & & Oligomeric $\alpha$-syn & & & \\
\hline & & & & & & Fibrillar $\alpha$-syn & $=$ & ns & \\
\hline \multirow{14}{*}{ Plasma } & \multirow{2}{*}{$\begin{array}{l}\text { PD: } 267 \\
\text { Ctrl: } 215\end{array}$} & \multirow{2}{*}{$\begin{array}{c}\text { L1CAM } \\
\text { immunocapture }\end{array}$} & & \multirow{2}{*}{$x$} & \multirow{2}{*}{+} & \multirow{2}{*}{$\begin{array}{c}\alpha \text {-syn } \\
\text { Ratio EV } \\
\alpha \text {-syn/plasma } \alpha \text {-syn }\end{array}$} & \multirow{2}{*}{$\uparrow$} & AUC: 0.654 & \multirow{2}{*}{ [158] } \\
\hline & & & & & & & & AUC: 0.657 & \\
\hline & $\begin{array}{l}\text { PD: } 39 \\
\text { Ctrl: } 33\end{array}$ & $\begin{array}{c}\text { Differential } \\
\text { centrifugation }\end{array}$ & $\mathrm{x}$ & $\mathrm{x}$ & $+;-$ & $\begin{array}{c}\alpha \text {-syn } \\
\text { Ratio EV } \\
\alpha \text {-syn/plasma } \alpha \text {-syn }\end{array}$ & $\uparrow$ & $p<0.001$ & [118] \\
\hline & \multirow{3}{*}{$\begin{array}{l}\text { PD: } 20 \\
\text { Ctrl: } 15\end{array}$} & \multirow{3}{*}{$\begin{array}{c}\text { Differential } \\
\text { centrifugation }\end{array}$} & & \multirow{3}{*}{$\mathrm{x}$} & \multirow{3}{*}{$+;-$} & $\alpha$-syn & & $p=0.02$ & \multirow{3}{*}{ [103] } \\
\hline & & & & & & $\begin{array}{l}\text { Monomeric and } \\
\text { oligomeric } \alpha \text {-syn }\end{array}$ & $\uparrow$ & $\begin{aligned} p= & 0.0002 ; p< \\
& 0.0001\end{aligned}$ & \\
\hline & & & & & & Fibrillar $\alpha$-syn & $=$ & ns & \\
\hline & \multirow{3}{*}{$\begin{array}{l}\text { PD: } 39 \\
\text { Ctrl: } 40\end{array}$} & \multirow{3}{*}{$\begin{array}{c}\text { ExoQuick + } \\
\text { immunoprecipitation } \\
\text { with L1CAM }\end{array}$} & & \multirow{3}{*}{$\mathrm{x}$} & & $\alpha$-syn & \multirow{3}{*}{$\uparrow$} & AUC: 0.654 & \multirow{3}{*}{ [159] } \\
\hline & & & & & & DJ-1 & & AUC: 0.703 & \\
\hline & & & & & & $\begin{array}{c}\text { Ratio EV } \\
\text { DJ-1/plasma DJ-1 }\end{array}$ & & AUC: 0.724 & \\
\hline & \multirow{3}{*}{$\begin{array}{l}\text { PD: } 16 \\
\text { Ctrl: } 8\end{array}$} & \multirow{3}{*}{$\begin{array}{l}\text { Size exclusion } \\
\text { chromatography }\end{array}$} & & \multirow{3}{*}{$\mathrm{x}$} & \multirow{3}{*}{+} & Clusterin & & & \multirow{3}{*}{ [161] } \\
\hline & & & & & & Complement C1r & $\downarrow$ & $p<0.05$ & \\
\hline & & & & & & Apolipoprotein A1 & & & \\
\hline & \multirow{2}{*}{$\begin{array}{l}\text { PD: } 52 \\
\text { Ctrl: } 48\end{array}$} & \multirow{2}{*}{$\begin{array}{l}\text { PureExo exosome } \\
\text { isolation kit }\end{array}$} & & $\gamma$ & 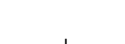 & miR-331-5p & $\uparrow$ & AUC: 0.849 & {$[160]$} \\
\hline & & & & $\lambda$ & $T^{+}$ & miR-505 & $\downarrow$ & AUC: 0.898 & {$[102]$} \\
\hline
\end{tabular}


Table 2. Cont

\begin{tabular}{|c|c|c|c|c|c|c|c|c|c|}
\hline \multirow[b]{2}{*}{ Source } & \multirow[b]{2}{*}{ Cohort } & \multirow[b]{2}{*}{ EV Isolation Method } & \multicolumn{3}{|c|}{ EV QC } & \multicolumn{4}{|c|}{ PD vs. ctrl } \\
\hline & & & NTA & TEM & $\begin{array}{c}\text { EV } \\
\text { Markers }\end{array}$ & Biomarker & Result & Statistics & Reference \\
\hline \multirow{15}{*}{ Serum } & \multirow{4}{*}{$\begin{array}{l}\text { PD: } 14 \\
\text { Ctrl: } 14\end{array}$} & \multirow{4}{*}{ Differential centrifugation } & \multirow{4}{*}{$\mathrm{x}$} & \multirow{4}{*}{$\mathrm{x}$} & \multirow{4}{*}{$+;-$} & $\alpha$-syn & & $p<0.05$ & \multirow{4}{*}{ [104] } \\
\hline & & & & & & $\begin{array}{l}\text { Monomeric and } \\
\text { oligomeric } \alpha \text {-syn }\end{array}$ & $\uparrow$ & _ & \\
\hline & & & & & & pS129 $\alpha$-syn & & & \\
\hline & & & & & & TNF- $\alpha$ and IL-1 $\beta$ & & $p<0.05$ & \\
\hline & \multirow{2}{*}{$\begin{array}{l}\text { PD: } 230 \\
\text { Ctrl: } 144\end{array}$} & \multirow{2}{*}{$\begin{array}{c}\text { Differential centrifugation + } \\
\text { immunoprecipitation with } \\
\text { L1CAM }\end{array}$} & \multirow{2}{*}{$x$} & & \multirow{2}{*}{+} & $\alpha$-syn & $\uparrow$ & AUC: 0.86 & \multirow{2}{*}{ [160] } \\
\hline & & & & & & Clusterin & $=$ & ns & \\
\hline & $\begin{array}{l}\text { PD: } 22 \\
\text { Ctrl: } 18\end{array}$ & Size exclusion chromatography & & $\mathrm{x}$ & $+;-$ & Raman spectrum & $\neq$ & AUC: 0.71 & [163] \\
\hline & $\begin{array}{l}\text { PD: } 36 \\
\text { Ctrl: } 36\end{array}$ & Differential centrifugation & $\mathrm{x}$ & $\mathrm{x}$ & $+;-$ & Protein composition & $\neq$ & NA & [156] \\
\hline & $\begin{array}{l}\text { PD: } 20 \\
\text { Ctrl: } 10\end{array}$ & Differential centrifugation & & & & Protein composition & $\neq$ & NA & [164] \\
\hline & \multirow{3}{*}{$\begin{array}{l}\text { PD: } 16 \\
\text { Ctrl: } 12\end{array}$} & \multirow{3}{*}{ Differential centrifugation } & & \multirow{3}{*}{$\mathrm{x}$} & \multirow{3}{*}{$+;-$} & ATP5A & \multirow{3}{*}{$\downarrow$} & \multirow{3}{*}{$p<0.0001$} & \multirow{3}{*}[157,165]{} \\
\hline & & & & & & NDUFS3 & & & \\
\hline & & & & & & SDHB & & & \\
\hline & \multirow{3}{*}{$\begin{array}{l}\text { PD: } 109 \\
\text { Ctrl: } 40\end{array}$} & \multirow{3}{*}{ Total exosome isolation reagent } & & & \multirow{3}{*}{+} & miR-24 & & AUC: 0.908 & \multirow{3}{*}{ [166] } \\
\hline & & & & & & miR-195 & $\uparrow$ & AUC: 0.697 & \\
\hline & & & & & & $\mathrm{miR}-19 \mathrm{~b}$ & $\downarrow$ & AUC: 0.753 & \\
\hline \multirow{5}{*}{ Urine } & $\begin{array}{l}\text { PD: } 20 \\
\text { Ctrl: } 15\end{array}$ & Differential centrifugation & & $\mathrm{x}$ & + & LRKK2 & $=$ & ns & [167] \\
\hline & \multirow{2}{*}{$\begin{array}{l}\text { PD: } 26 \\
\text { Ctrl: } 21\end{array}$} & \multirow{2}{*}{ Microfiltration } & & & \multirow{2}{*}{+} & DJ-1 & $\begin{array}{c}\uparrow \text { (only in } \\
\text { males) }\end{array}$ & $p=0.0493$ & \multirow{2}{*}{ [168] } \\
\hline & & & & & & LRKK2 & $=$ & ns & \\
\hline & $\begin{array}{c}\text { LRKK2+ PD: } \\
21 \\
\text { LRKK2- PD: }\end{array}$ & Differential centrifugation & & & & Ratio pSer1292 & $\begin{array}{l}\text { LRKK2+ } \\
\text { PD/LRKK2- } \\
\text { PD: } \uparrow\end{array}$ & AUC: 1 & [169] \\
\hline & $\begin{array}{c}20 \\
\text { LRKK2+ } \\
\text { noPD: } 16\end{array}$ & & & & + & $\begin{array}{c}\text { LRKK2/total } \\
\text { LRKK2 }\end{array}$ & $\begin{array}{l}\text { LRKK2+ } \\
\text { PD/LRKK2+ } \\
\text { noPD: } \uparrow\end{array}$ & AUC: 0.844 & \\
\hline
\end{tabular}


Table 2. Cont.

\begin{tabular}{|c|c|c|c|c|c|c|c|c|c|}
\hline & & & & EV QC & & & & ctrl & \\
\hline Source & Cohort & EV Isolation Method & NTA & TEM & $\begin{array}{c}\text { EV } \\
\text { Markers }\end{array}$ & Biomarker & Result & Statistics & Reference \\
\hline \multirow{3}{*}{ Urine } & $\begin{array}{l}\text { PD: } 79 \\
\text { Ctrl: } 79\end{array}$ & $\begin{array}{l}\text { Differential } \\
\text { centrifugation }\end{array}$ & & $x$ & + & pSer1292 LRKK2 & $\uparrow$ & $p=0.0014$ & [170] \\
\hline & PD: 28 & Differential & \multirow{2}{*}{$x$} & \multirow{2}{*}{$x$} & & SNAP23 & \multirow{2}{*}{$\uparrow$} & AUC: 0.8 & \multirow{2}{*}{ [171] } \\
\hline & Ctrl: 22 & centrifugation & & & & Calbindin & & AUC: 0.75 & \\
\hline \multirow{5}{*}{ Saliva } & \multirow{4}{*}{$\begin{array}{l}\text { PD: } 74 \\
\text { Ctrl: } 60\end{array}$} & \multirow{4}{*}{$\begin{array}{c}\text { XYCQ EV } \\
\text { enrichment kit }\end{array}$} & \multirow{4}{*}{$\mathrm{x}$} & \multirow{4}{*}{$x$} & \multirow{4}{*}{+} & $\alpha$-syn & & & \multirow{4}{*}{ [172] } \\
\hline & & & & & & pS129 $\alpha$-syn & $=$ & ns & \\
\hline & & & & & & Oligomeric $\alpha$-syn & \multirow[b]{2}{*}{$\uparrow$} & AUC: 0.941 & \\
\hline & & & & & & $\begin{array}{c}\text { Ratio } \\
\alpha \text {-syn/oligomeric } \\
\alpha \text {-syn }\end{array}$ & & AUC: 0.772 & \\
\hline & $\begin{array}{l}\text { PD: } 18 \\
\text { Ctrl: } 5\end{array}$ & PEG precipitation & $\mathrm{x}$ & & + & $\alpha$-syn & $\uparrow$ & $p<0.0004$ & [173] \\
\hline
\end{tabular}

This table only discusses results obtained in Parkinson's disease (PD) patients and controls (ctrl). In the extracellular vesicle (EV) markers column, the + symbol indicates the assessment of typical EV markers whereas the symbol indicates the a pasment of non-EV markers. For statistics, preferably the area under the receiver operating curve (AUC) or alternatively the alternatively microscopy; CSF, cebrospinal fluid, L1CAM, L1 cell a $p$-vici, ATP5A, adenosine triphosphate 5A; NDUFS3, NADH:ubiquinone oxidoreductase subunit S3; SDHB, succinate dehydrogenase complex iron sulfur subunit B; LRKK2, leucine-rich repeat kinase 2; SNAP23, synaptosomal-associated protein 23 
Next to $\alpha$-syn, other EV-related proteins that could also serve as biomarker candidates were identified. DJ-1 is significantly elevated in EVs isolated from plasma of PD patients compared to controls [159]. Additionally, certain miRNAs are more (i.e., miR-24 and miR-195) or less (i.e., miR-19b) abundant in serum EVs of PD patients [166]. In plasma-derived EVs of PD patients, miR-331-5p is increased, whereas miR-505 is decreased [162]. Several mitochondrial markers (i.e., ATP5A, NDUFS3 and SDHB) are decreased in serum EVs of PD patients as well $[157,165]$. More generally, a Raman spectroscopy analysis revealed that the molecular fingerprint of EVs isolated from the serum of PD patients is different compared to controls. Therefore, this technique might hold promise for the diagnosis and monitoring of PD once further optimized and validated [163]. Proteomics analyses from serum-isolated EVs revealed that several proteins are differentially abundant between PD patients and controls $[156,161,164]$. For example, EVs from the plasma of PD patients contain less clusterin, complement C1r and apolipoprotein A1 (ApoA-1) compared to controls [161]. Of particular interest, certain proteins are significantly altered between different PD stages as well, underlining their potential as biomarkers to trace the progression of PD [161,164]. For example, ApoA-1 is significantly lower in plasma EVs of H\&Y stage III compared to stage II PD patients [161]. Additionally, in serum-derived EVs, a proteomics approach identified seven proteins that are progressively upregulated from mild to severe $\mathrm{PD}$, whereas seven other proteins progressively decreased [164]. These progressively upregulated proteins include clusterin and complement C1r, which contradicts the results that were obtained in plasma-derived EVs [161,164]. Next to potential prognostic biomarkers, some promising results suggesting the use of EV biomarkers to distinguish PD from other disorders were reported. In CSF, both EV-associated $\alpha$-syn and the ratio of EV $\alpha$-syn to the total number of EVs could discriminate between PD, dementia with Lewy bodies and neurological controls (i.e., polyneuropathy and progressive supranuclear palsy patients) with relatively high sensitivity and specificity [95]. Furthermore, the combination of $\alpha$-syn and clusterin in serum NDEs allows us to discriminate between PD and both MSA (AUC: 0.91) and other proteinopathies (i.e., frontotemporal dementia, corticobasal syndrome and PSP) (AUC: 0.98) [160].

Not only are CSF and plasma useful sources of potential EV-associated biomarker candidates, since interesting results were obtained in the easily accessible biofluids saliva and urine as well. The number of EVs in saliva from PD patients is increased compared to controls [173]. Additionally, saliva-derived EVs from PD patients contain higher levels of oligomeric $\alpha$-syn, whereas the ratio of total $\alpha$-syn to oligomeric $\alpha$-syn is also increased compared to controls [172]. However, no association with disease severity was found [172]. In urinary EVs, SNAP23 and calbindin are elevated in PD patients compared to controls [171]. Similar results were obtained for DJ-1, although this only holds true for samples derived from males [168]. In contrast, no differences in leucine-rich repeat kinase 2 (LRRK2) were present [168], which was reported in other studies as well [167,169]. Mutations in LRKK2, which can be phosphorylated at multiple sites, are one of the most commonly known genetic causes of PD [174]. Interestingly, the ratio of Ser(P)-1292 LRRK2 to total LRKK2 is increased in urinary EVs of PD patients with and without LRKK2 mutations, whereby the Ser(P)-1292 LRRK2 levels in the latter group correlate with several non-motor aspects of PD $[169,170]$.

One study already reported the use of EVs for treatment follow-up in a clinical trial, namely the Exenatide-PD trial. In this trial, the treatment group demonstrated a slight improvement in their UPDRS motor score, whereas the control group continued to worsen [175]. Concomitantly, the levels of IRS-1-pTyr increased in serum-derived NDEs from the Exenatide group compared to the placebo group, suggesting an increase in brain insulin signaling pathways due to the treatment. Additionally, an increase in downstream effector molecules (i.e., total and phosphorylated mechanistic target of rapamycin (mTOR)) in these serum NDEs could be correlated with the improved UPDRS motor score in the treatment group [176]. These data support the usability of EVs as tools to validate a treatment response. 


\section{Conclusions}

CSF is the only biofluid that is currently included in the guidelines for the biomarker-based definition of AD provided by the research framework of the National Institute on Aging-Alzheimer's Association (NIA-AAA) and the International Working Group (IWG) $[177,178]$. The CSF biomarker profile defining $A D$ consists of a low CSF $A \beta_{1-42}$ or $A \beta_{1-42} / A \beta_{1-40}$ ratio, elevated CSF $p$-Tau and elevated CSF t-Tau $[177,178]$. This CSF biomarker profile is not standardly used in clinical practice but can increase diagnostic accuracy when the clinical diagnosis is inconclusive [179]. For PD, no validated biomarker profile is available yet. PD diagnosis is based on clinical symptoms as described in the International Parkinson and Movement Disorder Society Clinical Diagnostic Criteria for PD [180]. Therefore, there is a great need for novel and additional biomarkers with the ability to predict, diagnose and follow-up disease. Preferentially, these biomarkers should be derived from easily accessible biofluids. Although the collection of CSF via a lumbar puncture is a safe procedure [181], it still remains rather invasive. However, the alternative use of blood-based candidate biomarkers implicates several challenges. Blood is a complex fluid in which potential biomarkers are susceptible to potential proteolytic degradation and in which they are generally present at a low concentration [182,183]. The usability of $\alpha$-syn as a reliable biomarker in blood is further complicated because the majority of $\alpha$-syn that is present in blood derives from red blood cells [184]. EVs can overcome some of these challenges and therefore provide a highly interesting alternative biomarker source. Because of their ability to cross the brain barriers [185], they can be detected in peripheral biofluids in which they protect their cargo from degradation. Furthermore, the biomarker of interest is often enriched in EVs in comparison with the total biofluid. This can improve the measurement sensitivity, lower the detection threshold and enhance the signal-to-noise ratio. The use of specific markers to enrich for EVs derived from cellular sources that are known to be involved in the disease process even further improves these advantages [124]. Nonetheless, the use of EVs as biomarkers also comes with several considerations. A variety of isolation methods are currently available to separate EVs from biological fluids, as is reflected in Tables 1 and 2. Each method has its own specificity and efficiency, thereby influencing the identification of EV cargo [186]. Quality control measures are of utmost importance to verify the depletion of contaminants and the successful separation of EVs from a given biofluid [16]. Additionally, pre-analytical variables in collecting (e.g., timepoint of sampling), processing (e.g., centrifugation speed) and storing (e.g., temperature) samples prior to the EV isolation can influence the obtained results $[187,188]$. Punctiliously reporting all experimental parameters and quality control measurements as proposed by the transparent reporting and centralizing knowledge in EV research (EV-TRACK) initiative and the minimal information for studies of EVs (MISEV) guidelines is therefore indispensable for reproducible and reliable EV research $[16,186]$. Prior to the potential implementation of EV assays in the clinic, fully validated and standardized protocols will be needed [189]. Furthermore, the identified EV-related biomarker candidates will need to be validated in large datasets to verify the initial results. Although there is still a long way to go, EV biomarker research is an exciting field which holds great promise to be of value to patients in the future.

Author Contributions: C.V. wrote the manuscript. A.B., C.V.C. and R.E.V. critically revised the manuscript. All authors have read and agreed to the published version of the manuscript.

Funding: This work was supported by the Research Council of Ghent University, the Belgian Foundation of Alzheimer's Research (SAO), and the Research Foundation Flanders (FWO Vlaanderen).

Conflicts of Interest: The authors declare no conflict of interest.

\section{References}

1. Feigin, V.L.; Nichols, E.; Alam, T.; Bannick, M.S.; Beghi, E.; Blake, N.; Culpepper, W.J.; Dorsey, E.R.; Elbaz, A.; Ellenbogen, R.G.; et al. Global, regional, and national burden of neurological disorders, 1990-2016: A systematic analysis for the Global Burden of Disease Study 2016. Lancet Neurol. 2019, 18, 459-480. [CrossRef] 
2. Iadanza, M.G.; Jackson, M.P.; Hewitt, E.W.; Ranson, N.A.; Radford, S.E. A new era for understanding amyloid structures and disease. Nat. Rev. Mol. Cell Biol. 2018, 19, 755-773. [CrossRef] [PubMed]

3. Chen, X.-Q.; Mobley, W.C. Alzheimer Disease Pathogenesis: Insights From Molecular and Cellular Biology Studies of Oligomeric A $\beta$ and Tau Species. Front. Neurosci. 2019, 13, 659. [CrossRef] [PubMed]

4. DeTure, M.A.; Dickson, D.W. The neuropathological diagnosis of Alzheimer's disease. Mol. Neurodegener. 2019, 14, 32. [CrossRef]

5. Hijaz, B.A.; Volpicelli-Daley, L.A. Initiation and propagation of $\alpha$-synuclein aggregation in the nervous system. Mol. Neurodegener. 2020, 15, 19. [CrossRef]

6. Poewe, W.; Seppi, K.; Tanner, C.M.; Halliday, G.M.; Brundin, P.; Volkmann, J.; Schrag, A.-E.; Lang, A.E. Parkinson disease. Nat. Rev. Dis. Primers 2017, 3, nrdp201713. [CrossRef]

7. Braak, H.; Alafuzoff, I.; Arzberger, T.; Kretzschmar, H.; Tredici, K.D. Staging of Alzheimer disease-associated neurofibrillary pathology using paraffin sections and immunocytochemistry. Acta Neuropathol. 2006, 112, 389-404. [CrossRef]

8. Braak, H.; Tredici, K.D.; Rüb, U.; de Vos, R.A.I.; Steur, E.N.H.J.; Braak, E. Staging of brain pathology related to sporadic Parkinson's disease. Neurobiol. Aging 2003, 24, 197-211. [CrossRef]

9. Uemura, N.; Uemura, M.T.; Luk, K.C.; Lee, V.M.Y.; Trojanowski, J.Q. Cell-to-Cell Transmission of Tau and $\alpha$-Synuclein. Trends Mol. Med. 2020. [CrossRef]

10. Braak, H.; Braak, E. Neuropathological stageing of Alzheimer-related changes. Acta Neuropathol. 1991, 82, 239-259. [CrossRef]

11. Mroczko, B.; Groblewska, M.; Litman-Zawadzka, A.; Kornhuber, J.; Lewczuk, P. Amyloid $\beta$ oligomers (AßOs) in Alzheimer's disease. J. Neural Transm. Vienna Austria 2017, 125, 177-191. [CrossRef] [PubMed]

12. Haass, C.; Selkoe, D.J. Soluble protein oligomers in neurodegeneration: Lessons from the Alzheimer's amyloid $\beta$-peptide. Nat. Rev. Mol. Cell Biol. 2007, 8, 101-112. [CrossRef] [PubMed]

13. McAllister, B.B.; Lacoursiere, S.G.; Sutherland, R.J.; Mohajerani, M.H. Intracerebral seeding of amyloid- $\beta$ and tau pathology in mice: Factors underlying prion-like spreading and comparisons with $\alpha$-synuclein. Neurosci. Biobehav. Rev. 2020, 112, 1-27. [CrossRef] [PubMed]

14. Hill, A.F. Extracellular Vesicles and Neurodegenerative Diseases. J. Neurosci. 2019, 39, 9269-9273. [CrossRef]

15. van Niel, G.; D'Angelo, G.; Raposo, G. Shedding light on the cell biology of extracellular vesicles. Nat. Rev. Mol. Cell Biol. 2018, 19, 213. [CrossRef]

16. Théry, C.; Witwer, K.W.; Aikawa, E.; Alcaraz, M.J.; Anderson, J.D.; Andriantsitohaina, R.; Antoniou, A.; Arab, T.; Archer, F.; Atkin-Smith, G.K. Minimal information for studies of extracellular vesicles 2018 (MISEV2018): A position statement of the International Society for Extracellular Vesicles and update of the MISEV2014 guidelines. J. Extracell. Vesicles 2018, 7, 1535750. [CrossRef]

17. Zheng, H.; Molecular, K.-E.H. Biology and pathophysiology of the amyloid precursor protein. Mol. Neurodegener. 2011, 6, 1-16. [CrossRef]

18. Haass, C.; Kaether, C.; Thinakaran, G.; Sisodia, S. Trafficking and proteolytic processing of APP. Cold Spring Harbor Perspect. Med. 2012, 2, a006270. [CrossRef]

19. O'Brien, R.J.; Wong, P.C. Amyloid precursor protein processing and Alzheimer's disease. Annu. Rev. Neurosci. 2011, 34, 185-204. [CrossRef]

20. Steiner, H.; Fukumori, A.; Tagami, S.; Okochi, M. Making the final cut: Pathogenic amyloid- $\beta$ peptide generation by $\gamma$-secretase. Cell Stress 2018, 2, 292. [CrossRef]

21. Qiu, T.; Liu, Q.; Chen, Y.-X.; Zhao, Y.-F.; Li, Y.-M. A $\beta 42$ and A $\beta$ 40: Similarities and differences: A $\beta$ PEPTIDE. J. Pept. Sci. 2015, 21, 522-529. [CrossRef] [PubMed]

22. Lichtenthaler, S.F. Alpha-Secretase Cleavage of the Amyloid Precursor Protein: Proteolysis Regulated by Signaling Pathways and Protein Trafficking. Curr. Alzheimer Res. 2012, 9, 165-177. [CrossRef] [PubMed]

23. Toh, W.; Gleeson, P.A. Dysregulation of intracellular trafficking and endosomal sorting in Alzheimer's disease: Controversies and unanswered questions. Biochem. J. 2016, 473, 1977-1993. [CrossRef]

24. Morel, E.; Chamoun, Z.; Lasiecka, Z.M.; Chan, R.B.; Williamson, R.L.; Vetanovetz, C.; Dall'Armi, C.; Simoes, S.; Jour, K.S.P.D.; McCabe, B.D.; et al. Phosphatidylinositol-3-phosphate regulates sorting and processing of amyloid precursor protein through the endosomal system. Nat. Commun. 2013, 4, 2250. [CrossRef] [PubMed]

25. Edgar, J.R.; Willén, K.; Gouras, G.K.; Sci, F.-C.E.J. ESCRTs regulate amyloid precursor protein sorting in multivesicular bodies and intracellular amyloid- $\beta$ accumulation. J. Cell Sci. 2015, 128, 2520-2528. [CrossRef] 
26. Cone, A.S.; Hurwitz, S.N.; Lee, G.S.; Yuan, X.; Zhou, Y.; Li, Y.; Meckes, D.G. Alix and Syntenin-1 direct amyloid precursor protein trafficking into extracellular vesicles. BMC Mol. Cell Biol. 2020, 21, 58. [CrossRef] [PubMed]

27. Choy, R.W.; Cheng, Z.; Schekman, R. Amyloid precursor protein (APP) traffics from the cell surface via endosomes for amyloid $\beta(\mathrm{A} \beta)$ production in the trans-Golgi network. Proc. Natl. Acad. Sci. USA 2012, 109, E2077-E2082. [CrossRef]

28. Miranda, A.M.; Lasiecka, Z.M.; Xu, Y.; Neufeld, J.; Shahriar, S.; Simoes, S.; Chan, R.B.; Oliveira, T.G.; Small, S.A.; Paolo, G.D. Neuronal lysosomal dysfunction releases exosomes harboring APP C-terminal fragments and unique lipid signatures. Nat. Commun. 2018, 9, 291. [CrossRef]

29. Eitan, E.; Hutchison, E.R.; Marosi, K.; Comotto, J.; Mustapic, M.; Nigam, S.M.; Suire, C.; Maharana, C.; Jicha, G.A.; Liu, D.; et al. Extracellular vesicle-associated A $\beta$ mediates trans-neuronal bioenergetic and $\mathrm{Ca}^{2+}$-handling deficits in Alzheimer's disease models. NPJ Aging Mech. Dis. 2016, 2, 16019. [CrossRef]

30. Verbeek, M.M.; Otte-Höller, I.; Fransen, J.A.; de Waal, R.M. Accumulation of the amyloid- $\beta$ precursor protein in multivesicular body-like organelles. J. Histochem. Cytochem. 2002, 50, 681-690. [CrossRef]

31. Langui, D.; Girardot, N.; El Hachimi, K.H.; Allinquant, B.; Blanchard, V.; Pradier, L.; Duyckaerts, C. Subcellular topography of neuronal A $\beta$ peptide in APPxPS1 transgenic mice. Am. J. Pathol. 2004, 165, 1465-1477. [CrossRef]

32. Vingtdeux, V.; Hamdane, M.; Loyens, A.; Gelé, P.; Drobeck, H.; Bégard, S.; Galas, M.-C.; Delacourte, A.; Beauvillain, J.-C.; Buée, L.; et al. Alkalizing Drugs Induce Accumulation of Amyloid Precursor Protein By-products in Luminal Vesicles of Multivesicular Bodies. J. Biol. Chem. 2007, 282, 18197-18205. [CrossRef] [PubMed]

33. Rajendran, L.; Honsho, M.; Zahn, T.R.; Keller, P.; Geiger, K.D.; Verkade, P.; Simons, K. Alzheimer's disease $\beta$-amyloid peptides are released in association with exosomes. Proc. Natl. Acad. Sci. USA 2006, 103, 11172-11177. [CrossRef] [PubMed]

34. Laulagnier, K.; Javalet, C.; Hemming, F.J.; Chivet, M.; Lachenal, G.; Blot, B.; Chatellard, C.; Sadoul, R. Amyloid precursor protein products concentrate in a subset of exosomes specifically endocytosed by neurons. Cell. Mol. Life Sci. 2017, 75, 757-773. [CrossRef] [PubMed]

35. Lauritzen, I.; Bécot, A.; Bourgeois, A.; Pardossi-Piquard, R.; Biferi, M.-G.; Barkats, M.; Checler, F. Targeting $\gamma$-secretase triggers the selective enrichment of oligomeric APP-CTFs in brain extracellular vesicles from Alzheimer cell and mouse models. Transl. Neurodegener. 2019, 8, 35. [CrossRef] [PubMed]

36. Perez-Gonzalez, R.; Gauthier, S.A.; Kumar, A.; Levy, E. The Exosome Secretory Pathway Transports Amyloid Precursor Protein Carboxyl-terminal Fragments from the Cell into the Brain Extracellular Space. J. Biol. Chem. 2012, 287, 43108-43115. [CrossRef]

37. Sannerud, R.; Esselens, C.; Ejsmont, P.; Mattera, R.; Rochin, L.; Tharkeshwar, A.K.; De Baets, G.; De Wever, V.; Habets, R.; Baert, V.; et al. Restricted Location of PSEN2/ $\gamma$-Secretase Determines Substrate Specificity and Generates an Intracellular A $\beta$ Pool. Cell 2016, 166, 193-208. [CrossRef]

38. Takahashi, R.H.; Milner, T.A.; Li, F.; Nam, E.E.; Edgar, M.A.; Yamaguchi, H.; Beal, M.F.; Xu, H.; Greengard, P.; Gouras, G.K. Intraneuronal Alzheimer A $\beta 42$ accumulates in multivesicular bodies and is associated with synaptic pathology. Am. J. Pathol. 2002, 161, 1869-1879. [CrossRef]

39. Takahashi, R.H.; Almeida, C.G.; Kearney, P.F.; Yu, F.; Lin, M.T.; Milner, T.A.; Gouras, G.K. Oligomerization of Alzheimer's $\beta$-amyloid within processes and synapses of cultured neurons and brain. J. Neurosci. 2004, 24, 3592-3599. [CrossRef]

40. Almeida, C.G.; Takahashi, R.H.; Gouras, G.K. $\beta$-Amyloid accumulation impairs multivesicular body sorting by inhibiting the ubiquitin-proteasome system. J. Neurosci. 2006, 26, 4277-4288. [CrossRef]

41. Sinha, M.S.; Ansell-Schultz, A.; Civitelli, L.; Hildesjö, C.; Larsson, M.; Lannfelt, L.; Ingelsson, M.; Hallbeck, M. Alzheimer's disease pathology propagation by exosomes containing toxic amyloid-beta oligomers. Acta Neuropathol. 2018, 136, 41-56. [CrossRef] [PubMed]

42. Esbjörner, E.K.; Chan, F.; Rees, E.; Erdelyi, M.; Luheshi, L.M.; Bertoncini, C.W.; Kaminski, C.F.; Dobson, C.M.; Kaminski Schierle, G.S. Direct Observations of Amyloid $\beta$ Self-Assembly in Live Cells Provide Insights into Differences in the Kinetics of $A \beta(1-40)$ and $A \beta(1-42)$ Aggregation. Chem. Biol. 2014, 21, 732-742. [CrossRef] [PubMed]

43. Hu, X.; Crick, S.L.; Bu, G.; Frieden, C.; Pappu, R.V.; Lee, J.M. Amyloid seeds formed by cellular uptake, concentration, and aggregation of the amyloid-beta peptide. Proc. Nat. Acad. Sci. USA 2009, 106, 20324-20329. [CrossRef] [PubMed] 
44. Peric, A.; Annaert, W. Early etiology of Alzheimer's disease: Tipping the balance toward autophagy or endosomal dysfunction? Acta Neuropathol. 2015, 129, 363-381. [CrossRef] [PubMed]

45. Pérez-González, R.; Kim, Y.; Miller, C.; Pacheco-Quinto, J.; Eckman, E.A.; Levy, E. Extracellular vesicles: Where the amyloid precursor protein carboxyl-terminal fragments accumulate and amyloid- $\beta$ oligomerizes. FASEB J. 2020, 34, 12922-12931. [CrossRef] [PubMed]

46. Sharples, R.A.; Vella, L.J.; Nisbet, R.M.; Naylor, R.; Perez, K.; Barnham, K.J.; Masters, C.L.; Hill, A.F. Inhibition of gamma-secretase causes increased secretion of amyloid precursor protein C-terminal fragments in association with exosomes. FASEB J. Off. Publ. Fed. Am. Soc. Exp. Biol. 2008, 22, 1469-1478. [CrossRef]

47. An, K.; Klyubin, I.; Kim, Y.; Jung, J.; Mably, A.J.; O’Dowd, S.T.; Lynch, T.; Kanmert, D.; Lemere, C.A.; Finan, G.M.; et al. Exosomes neutralize synaptic-plasticity-disrupting activity of $A \beta$ assemblies in vivo. Mol. Brain 2013, 6, 47. [CrossRef]

48. Yuyama, K.; Sun, H.; Mitsutake, S.; of Chemistry, I.-Y. Sphingolipid-modulated exosome secretion promotes clearance of amyloid- $\beta$ by microglia. J. Biol. Chem. 2012, 287, 10977-10989. [CrossRef]

49. Falker, C.; Hartmann, A.; Guett, I.; Dohler, F.; Altmeppen, H.; Betzel, C.; Schubert, R.; Thurm, D.; Wegwitz, F.; Joshi, P.; et al. Exosomal cellular prion protein drives fibrillization of amyloid beta and counteracts amyloid beta-mediated neurotoxicity. J. Neurochem. 2016, 137, 88-100. [CrossRef]

50. Dinkins, M.B.; Dasgupta, S.; Wang, G.; Zhu, G.; Bieberich, E. Exosome reduction in vivo is associated with lower amyloid plaque load in the 5XFAD mouse model of Alzheimer's disease. Neurobiol. Aging 2014, 35, 1792-1800. [CrossRef]

51. Chafekar, S.M.; Baas, F.; Scheper, W. Oligomer-specific A $\beta$ toxicity in cell models is mediated by selective uptake. Biochim. Biophys. Acta BBA Mol. Basis Dis. 2008, 1782, 523-531. [CrossRef] [PubMed]

52. LaFerla, F.M.; Green, K.N.; Oddo, S. Intracellular amyloid- $\beta$ in Alzheimer's disease. Nat. Rev. Neurosci. 2007, 8, 499-509. [CrossRef] [PubMed]

53. Gouras, G.K.; Tampellini, D.; Takahashi, R.H.; Capetillo-Zarate, E. Intraneuronal $\beta$-amyloid accumulation and synapse pathology in Alzheimer's disease. Acta Neuropathol. 2010, 119, 523-541. [CrossRef] [PubMed]

54. Yuyama, K.; Sun, H.; Sakai, S.; Mitsutake, S.; Okada, M.; Tahara, H.; Furukawa, J.-I.; Fujitani, N.; Shinohara, Y.; Igarashi, Y. Decreased Amyloid- $\beta$ Pathologies by Intracerebral Loading of Glycosphingolipid-enriched Exosomes in Alzheimer Model Mice. J. Biol. Chem. 2014, 289, 24488-24498. [CrossRef] [PubMed]

55. Yuyama, K.; Sun, H.; Usuki, S.; Sakai, S.; Hanamatsu, H.; Mioka, T.; Kimura, N.; Okada, M.; Tahara, H.; Furukawa, J.-I.; et al. A potential function for neuronal exosomes: Sequestering intracerebral amyloid- $\beta$ peptide. FEBS Lett. 2015, 589, 84-88. [CrossRef] [PubMed]

56. Yuyama, K.; Takahashi, K.; Usuki, S.; Mikami, D.; Sun, H.; Hanamatsu, H.; Furukawa, J.; Mukai, K.; Igarashi, Y. Plant sphingolipids promote extracellular vesicle release and alleviate amyloid- $\beta$ pathologies in a mouse model of Alzheimer's disease. Sci. Rep. 2019, 9, 1-11. [CrossRef] [PubMed]

57. Tamboli, I.Y.; Barth, E.; Christian, L.; Siepmann, M.; Kumar, S.; Singh, S.; Tolksdorf, K.; Heneka, M.T.; Lütjohann, D.; Wunderlich, P.; et al. Statins Promote the Degradation of Extracellular Amyloid $\beta$-Peptide by Microglia via Stimulation of Exosome-associated Insulin-degrading Enzyme (IDE) Secretion. J. Biol. Chem. 2010, 285, 37405-37414. [CrossRef]

58. Bulloj, A.; Leal, M.C.; Xu, H.; Castaño, E.M.; Morelli, L. Insulin-degrading enzyme sorting in exosomes: A secretory pathway for a key brain amyloid-beta degrading protease. J. Alzheimer's Dis. Jad. 2010, 19, 79-95. [CrossRef]

59. Simón, D.; García-García, E.; Royo, F.; Falcón-Pérez, J.M.; Avila, J. Proteostasis of tau. Tau overexpression results in its secretion via membrane vesicles. FEBS Lett. 2011, 586, 47-54. [CrossRef]

60. Dujardin, S.; Bégard, S.; Caillierez, R.; Lachaud, C.; Delattre, L.; Carrier, S.; Loyens, A.; Galas, M.-C.; Bousset, L.; Melki, R.; et al. Ectosomes: A New Mechanism for Non-Exosomal Secretion of Tau Protein. PLoS ONE 2014, 9, e100760. [CrossRef]

61. Kokubo, H.; Saido, T.C.; Iwata, N.; Helms, J.B.; Shinohara, R.; Yamaguchi, H. Part of membrane-bound A $\beta$ exists in rafts within senile plaques in Tg2576 mouse brain. Neurobiol. Aging 2005, 26, 409-418. [CrossRef] [PubMed]

62. Rajendran, L.; Knobloch, M.; Geiger, K.D.; Dienel, S.; Nitsch, R.; Simons, K.; Konietzko, U. Increased A $\beta$ Production Leads to Intracellular Accumulation of $A \beta$ in Flotillin-1-Positive Endosomes. Neurodegener. Dis. 2007, 4, 164-170. [CrossRef] [PubMed]

63. Asai, H.; Ikezu, S.; Tsunoda, S.; Medalla, M.; Luebke, J.; Haydar, T.; Wolozin, B.; Butovsky, O.; Kügler, S.; Ikezu, T. Depletion of microglia and inhibition of exosome synthesis halt tau propagation. Nat. Neurosci. 2015, 18, 1584-1593. [CrossRef] [PubMed] 
64. Wang, Y.; Balaji, V.; Kaniyappan, S.; Krüger, L.; Irsen, S.; Tepper, K.; Chandupatla, R.; Maetzler, W.; Schneider, A.; Mandelkow, E.; et al. The release and trans-synaptic transmission of Tau via exosomes. Mol. Neurodegener. 2017, 12, 5. [CrossRef]

65. Polanco, J.C.; Li, C.; Durisic, N.; Sullivan, R.; Götz, J. Exosomes taken up by neurons hijack the endosomal pathway to spread to interconnected neurons. Acta Neuropathol. Commun. 2018, 6, 10. [CrossRef]

66. Joshi, P.; Turola, E.; Ruiz, A.; Bergami, A.; Libera, D.D.; Benussi, L.; Giussani, P.; Magnani, G.; Comi, G.; Legname, G.; et al. Microglia convert aggregated amyloid- $\beta$ into neurotoxic forms through the shedding of microvesicles. Cell Death Differ. 2013, 21, 582-593. [CrossRef]

67. Nogueras-Ortiz, C.J.; Mahairaki, V.; Delgado-Peraza, F.; Das, D.; Avgerinos, K.; Eren, E.; Hentschel, M.; Goetzl, E.J.; Mattson, M.P.; Kapogiannis, D. Astrocyte- and Neuron-Derived Extracellular Vesicles from Alzheimer's Disease Patients Effect Complement-Mediated Neurotoxicity. Cells 2020, 9, 1618. [CrossRef]

68. Goetzl, E.J.; Schwartz, J.B.; Abner, E.L.; Jicha, G.A.; Kapogiannis, D. High complement levels in astrocyte-derived exosomes of Alzheimer disease. Ann. Neurol. 2018, 83, 544-552. [CrossRef]

69. Reilly, P.; Winston, C.N.; Baron, K.R.; Trejo, M.; Rockenstein, E.M.; Akers, J.C.; Kfoury, N.; Diamond, M.; Masliah, E.; Rissman, R.A.; et al. Novel human neuronal tau model exhibiting neurofibrillary tangles and transcellular propagation. Neurobiol. Dis. 2017, 106, 222-234. [CrossRef]

70. Polanco, J.C.; Scicluna, B.J.; Hill, A.F.; Götz, J. Extracellular Vesicles Isolated from the Brains of rTg4510 Mice Seed Tau Protein Aggregation in a Threshold-dependent Manner. J. Biol. Chem. 2016, 291, 12445-12466. [CrossRef]

71. Crotti, A.; Sait, H.R.; McAvoy, K.M.; Estrada, K.; Ergun, A.; Szak, S.; Marsh, G.; Jandreski, L.; Peterson, M.; Reynolds, T.L.; et al. BIN1 favors the spreading of Tau via extracellular vesicles. Sci. Rep. 2019, 9, 9477. [CrossRef] [PubMed]

72. Baker, S.; Polanco, J.C.; Götz, J. Extracellular Vesicles Containing P301L Mutant Tau Accelerate Pathological Tau Phosphorylation and Oligomer Formation but Do Not Seed Mature Neurofibrillary Tangles in ALZ17 Mice. J. Alzheimer's Dis. 2016, 54, 1207-1217. [CrossRef] [PubMed]

73. Aulston, B.; Liu, Q.; Mante, M.; Florio, J.; Rissman, R.A.; Yuan, S.H. Extracellular Vesicles Isolated from Familial Alzheimer's Disease Neuronal Cultures Induce Aberrant Tau Phosphorylation in the Wild-Type Mouse Brain. J. Alzheimer's Dis. 2019, 72, 575-585. [CrossRef] [PubMed]

74. Winston, C.N.; Aulston, B.; Rockenstein, E.M.; Adame, A.; Prikhodko, O.; Dave, K.N.; Mishra, P.; Rissman, R.A.; Yuan, S.H. Neuronal Exosome-Derived Human Tau is Toxic to Recipient Mouse Neurons in vivo. J. Alzheimer's Dis. Jad. 2018, 67, 541-553. [CrossRef]

75. Winston, C.N.; Goetzl, E.J.; Akers, J.C.; Carter, B.S.; Rockenstein, E.M.; Galasko, D.; Masliah, E.; Rissman, R.A. Prediction of conversion from mild cognitive impairment to dementia with neuronally derived blood exosome protein profile. Alzheimer's Dement. Diagn. Assess. Dis. Monit. 2016, 3, 63-72. [CrossRef]

76. Dinkins, M.B.; Enasko, J.; Hernandez, C.; Wang, G.; Kong, J.; Helwa, I.; Liu, Y.; Terry, A.V.; Bieberich, E. Neutral Sphingomyelinase-2 deficiency ameliorates Alzheimer's disease pathology and improves cognition in the 5XFAD mouse. J. Neurosci. 2016, 36, 8653-8667. [CrossRef]

77. Kanmert, D.; Cantlon, A.; Muratore, C.R.; Jin, M.; O’Malley, T.T.; Lee, G.; Young-Pearse, T.L.; Selkoe, D.J.; Walsh, D.M. C-Terminally Truncated Forms of Tau, But Not Full-Length Tau or Its C-Terminal Fragments, Are Released from Neurons Independently of Cell Death. J. Neurosci. 2015, 35, 10851-10865. [CrossRef]

78. Saman, S.; Kim, W.; Raya, M.; Visnick, Y.; Miro, S.; Saman, S.; Jackson, B.; McKee, A.C.; Alvarez, V.E.; Lee, N.C.; et al. Exosome-associated tau is secreted in tauopathy models and is selectively phosphorylated in cerebrospinal fluid in early Alzheimer disease. J. Biol. Chem. 2012, 287, 3842-3849. [CrossRef]

79. Borghi, R.; Marchese, R.; Negro, A.; Marinelli, L.; Forloni, G.; Zaccheo, D.; Abbruzzese, G.; Tabaton, M. Full length $\alpha$-synuclein is present in cerebrospinal fluid from Parkinson's disease and normal subjects. Neurosci. Lett. 2000, 287, 65-67. [CrossRef]

80. El-Agnaf, O.M.A.; Salem, S.A.; Paleologou, K.E.; Cooper, L.J.; Fullwood, N.J.; Gibson, M.J.; Curran, M.D.; Court, J.A.; Mann, D.M.A.; Ikeda, S.-I.; et al. $\alpha$-Synuclein implicated in Parkinson's disease is present in extracellular biological fluids, including human plasma. FASEB J. 2003, 17, 1-16. [CrossRef]

81. El-Agnaf, O.M.; Salem, S.A.; Paleologou, K.E.; Curran, M.D.; Gibson, M.J.; Court, J.A.; Schlossmacher, M.G.; Allsop, D. Detection of oligomeric forms of $\alpha$-synuclein protein in human plasma as a potential biomarker for Parkinson's disease. FASEB J. 2006, 20, 419-425. [CrossRef] [PubMed]

82. Lee, H.-J.J.; Patel, S.; Lee, S.-J.J. Intravesicular localization and exocytosis of alpha-synuclein and its aggregates. J. Neurosci. 2005, 25, 6016-6024. [CrossRef] [PubMed] 
83. Emmanouilidou, E.; Melachroinou, K.; Roumeliotis, T.; Garbis, S.D.; Ntzouni, M.; Margaritis, L.H.; Stefanis, L.; Vekrellis, K. Cell-produced alpha-synuclein is secreted in a calcium-dependent manner by exosomes and impacts neuronal survival. J. Neurosci. 2010, 30, 6838-6851. [CrossRef] [PubMed]

84. Jang, A.; Lee, H.-J.; Suk, J.-E.; Jung, J.-W.; Kim, K.-P.; Lee, S.-J. Non-classical exocytosis of $\alpha$-synuclein is sensitive to folding states and promoted under stress conditions. J. Neurochem. 2010, 113, 1263-1274. [CrossRef]

85. Kunadt, M.; Eckermann, K.; Stuendl, A.; Gong, J.; Russo, B.; Strauss, K.; Rai, S.; Kügler, S.; Lockhart, L.F.; Schwalbe, M.; et al. Extracellular vesicle sorting of $\alpha$-Synuclein is regulated by sumoylation. Acta Neuropathol. 2015, 129, 695-713. [CrossRef]

86. Spencer, B.; Kim, C.; Gonzalez, T.; Bisquertt, A.; Patrick, C.; Rockenstein, E.; Adame, A.; Lee, S.-J.; Desplats, P.; Masliah, E. $\alpha$-Synuclein interferes with the ESCRT-III complex contributing to the pathogenesis of Lewy body disease. Hum. Mol. Genet. 2016, 25, 1100-1115. [CrossRef]

87. Danzer, K.M.; Kranich, L.R.; Ruf, W.P.; Cagsal-Getkin, O.; Winslow, A.R.; Zhu, L.; Vanderburg, C.R.; McLean, P.J. Exosomal cell-to-cell transmission of alpha synuclein oligomers. Mol. Neurodegener. 2012, 7, 42. [CrossRef]

88. Alvarez-Erviti, L.; Seow, Y.; Schapira, A.H.; Gardiner, C.; Sargent, I.L.; Wood, M.J.A.; Cooper, J.M. Lysosomal dysfunction increases exosome-mediated alpha-synuclein release and transmission. Neurobiol. Dis. 2011, 42, 360-367. [CrossRef]

89. Grey, M.; Dunning, C.J.; Gaspar, R.; Grey, C.; Brundin, P.; Sparr, E.; Linse, S. Acceleration of $\alpha$-synuclein aggregation by exosomes. J. Biol. Chem. 2015, 290, 2969-2982. [CrossRef]

90. Gustafsson, G.; Lööv, C.; Persson, E.; Lázaro, D.F.; Takeda, S.; Bergström, J.; Erlandsson, A.; Sehlin, D.; Balaj, L.; György, B.; et al. Secretion and Uptake of $\alpha$-Synuclein Via Extracellular Vesicles in Cultured Cells. Cell. Mol. Neurobiol. 2018, 38, 1539-1550. [CrossRef]

91. Pan-Montojo, F.; Schwarz, M.; Winkler, C.; Arnhold, M.; O'Sullivan, G.A.; Pal, A.; Said, J.; Marsico, G.; Verbavatz, J.-M.; Rodrigo-Angulo, M.; et al. Environmental toxins trigger PD-like progression via increased alpha-synuclein release from enteric neurons in mice. Sci. Rep. 2012, 2, 898. [CrossRef] [PubMed]

92. Minakaki, G.; Menges, S.; Kittel, A.; Emmanouilidou, E.; Schaeffner, I.; Barkovits, K.; Bergmann, A.; Rockenstein, E.; Adame, A.; Marxreiter, F.; et al. Autophagy inhibition promotes SNCA/alpha-synuclein release and transfer via extracellular vesicles with a hybrid autophagosome-exosome-like phenotype. Autophagy 2018, 14, 98-119. [CrossRef] [PubMed]

93. Ejlerskov, P.; Rasmussen, I.; Nielsen, T.T.; Bergström, A.-L.; Tohyama, Y.; Jensen, P.H.; Vilhardt, F. Tubulin Polymerization-promoting Protein (TPPP/p25 $\alpha$ ) Promotes Unconventional Secretion of $\alpha$-Synuclein through Exophagy by Impairing Autophagosome-Lysosome Fusion. J. Biol. Chem. 2013, 288, 17313-17335. [CrossRef] [PubMed]

94. Delenclos, M.; Trendafilova, T.; Mahesh, D.; Baine, A.M.; Moussaud, S.; Yan, I.K.; Patel, T.; McLean, P.J. Investigation of Endocytic Pathways for the Internalization of Exosome-Associated Oligomeric Alpha-Synuclein. Front. Neurosci. 2017, 11, 172. [CrossRef] [PubMed]

95. Stuendl, A.; Kunadt, M.; Kruse, N.; Bartels, C.; Moebius, W.; Danzer, K.M.; Mollenhauer, B.; Schneider, A. Induction of -synuclein aggregate formation by CSF exosomes from patients with Parkinson's disease and dementia with Lewy bodies. Brain 2015, 139, 481-494. [CrossRef]

96. Hasegawa, T.; Konno, M.; Baba, T.; Sugeno, N.; Kikuchi, A.; Kobayashi, M.; Miura, E.; Tanaka, N.; Tamai, K.; Furukawa, K.; et al. The AAA-ATPase VPS4 Regulates Extracellular Secretion and Lysosomal Targeting of

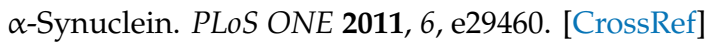

97. Karampetsou, M.; Sykioti, V.S.; Leandrou, E.; Melachroinou, K.; Lambiris, A.; Giannelos, A.; Emmanouilidou, E.; Vekrellis, K. Intrastriatal Administration of Exosome-Associated Pathological Alpha-Synuclein Is Not Sufficient by Itself to Cause Pathology Transmission. Front. Neurosci. 2020, 14, 246. [CrossRef]

98. Poehler, A.-M.; Xiang, W.; Spitzer, P.; May, V.E.L.; Meixner, H.; Rockenstein, E.; Chutna, O.; Outeiro, T.F.; Winkler, J.; Masliah, E.; et al. Autophagy modulates SNCA/ $\alpha$-synuclein release, thereby generating a hostile microenvironment. Autophagy 2014, 10, 2171-2192. [CrossRef]

99. Zhang, S.; Eitan, E.; Wu, T.-Y.; Mattson, M.P. Intercellular transfer of pathogenic $\alpha$-synuclein by extracellular vesicles is induced by the lipid peroxidation product 4-hydroxynonenal. Neurobiol. Aging 2018, 61, 52-65. [CrossRef]

100. Sackmann, V.; Sinha, M.S.; Sackmann, C.; Civitelli, L.; Bergström, J.; Ansell-Schultz, A.; Hallbeck, M. Inhibition of nSMase2 Reduces the Transfer of Oligomeric $\alpha$-Synuclein Irrespective of Hypoxia. Front. Mol. Neurosci. 2019, 12, 200. [CrossRef] 
101. Guo, M.; Wang, J.; Zhao, Y.; Feng, Y.; Han, S.; Dong, Q.; Cui, M.; Tieu, K. Microglial exosomes facilitate $\alpha$-synuclein transmission in Parkinson's disease. Brain 2020, 143, 1476-1497. [CrossRef] [PubMed]

102. Ngolab, J.; Trinh, I.; Rockenstein, E.; Mante, M.; Florio, J.; Trejo, M.; Masliah, D.; Adame, A.; Masliah, E.; Rissman, R.A. Brain-derived exosomes from dementia with Lewy bodies propagate $\alpha$-synuclein pathology. Acta Neuropathol. Commun. 2017, 5, 46. [CrossRef] [PubMed]

103. Xia, Y.; Zhang, G.; Han, C.; Ma, K.; Guo, X.; Wan, F.; Kou, L.; Yin, S.; Liu, L.; Huang, J.; et al. Microglia as modulators of exosomal alpha-synuclein transmission. Cell Death Dis. 2019, 10, 174. [CrossRef] [PubMed]

104. Han, C.; Xiong, N.; Guo, X.; Huang, J.; Ma, K.; Liu, L.; Xia, Y.; Shen, Y.; Li, J.; Jiang, H.; et al. Exosomes from patients with Parkinson's disease are pathological in mice. J. Mol. Med. 2019, 97, 1329-1344. [CrossRef]

105. Chang, C.; Lang, H.; Geng, N.; Wang, J.; Li, N.; Wang, X. Exosomes of BV-2 cells induced by alpha-synuclein: Important mediator of neurodegeneration in PD. Neurosci. Lett. 2013, 548, 190-195. [CrossRef]

106. Andruska, K.M.; Racette, B.A. Neuromythology of Manganism. Curr. Epidemiol. Rep. 2015, 2, 143-148. [CrossRef]

107. Harischandra, D.S.; Rokad, D.; Neal, M.L.; Ghaisas, S.; Manne, S.; Sarkar, S.; Panicker, N.; Zenitsky, G.; Jin, H.; Lewis, M.; et al. Manganese promotes the aggregation and prion-like cell-to-cell exosomal transmission of $\alpha$-synuclein. Sci Signal. 2019, 12, eaau4543. [CrossRef]

108. Tanner, C.M.; Kamel, F.; Ross, G.W.; Hoppin, J.A.; Goldman, S.M.; Korell, M.; Marras, C.; Bhudhikanok, G.S.; Kasten, M.; Chade, A.R.; et al. Rotenone, paraquat, and Parkinson's disease. Environ. Health Persp. 2011, 119, 866-872. [CrossRef]

109. Moors, T.; Paciotti, S.; Chiasserini, D.; Calabresi, P.; Parnetti, L.; Beccari, T.; Berg, W.D.J.v.d. Lysosomal Dysfunction and $\alpha$-Synuclein Aggregation in Parkinson's Disease: Diagnostic Links. Mov. Disord. 2016, 31, 791-801. [CrossRef]

110. Wallings, R.L.; Humble, S.W.; Ward, M.E.; Wade-Martins, R. Lysosomal Dysfunction at the Centre of Parkinson's Disease and Frontotemporal Dementia/Amyotrophic Lateral Sclerosis. Trends Neurosci. 2019, 42, 899-912. [CrossRef]

111. Baixauli, F.; López-Otín, C.; Mittelbrunn, M. Exosomes and autophagy: Coordinated mechanisms for the maintenance of cellular fitness. Front. Immunol. 2014, 5, 403. [CrossRef] [PubMed]

112. Fussi, N.; Höllerhage, M.; Chakroun, T.; Nykänen, N.-P.; Rösler, T.W.; Koeglsperger, T.; Wurst, W.; Behrends, C.; Höglinger, G.U. Exosomal secretion of $\alpha$-synuclein as protective mechanism after upstream blockage of macroautophagy. Cell Death Dis. 2018, 9, 757. [CrossRef] [PubMed]

113. Sidransky, E.; Nalls, M.A.; Aasly, J.O.; Aharon-Peretz, J.; Annesi, G.; Barbosa, E.R.; Bar-Shira, A.; Berg, D.; Bras, J.; Brice, A.; et al. Multicenter Analysis of Glucocerebrosidase Mutations in Parkinson's Disease. N. Engl. J. Med. 2009, 361, 1651-1661. [CrossRef] [PubMed]

114. Gegg, M.E.; Burke, D.; Heales, S.J.; Cooper, J.M.; Hardy, J.; Wood, N.W.; Schapira, A.H. Glucocerebrosidase deficiency in substantia nigra of parkinson disease brains. Ann. Neurol. 2012, 72, 455-463. [CrossRef] [PubMed]

115. Rocha, E.M.; Smith, G.A.; Park, E.; Cao, H.; Brown, E.; Hallett, P.; Isacson, O. Progressive decline of glucocerebrosidase in aging and P arkinson's disease. Ann. Clin. Transl. Neurol. 2015, 2, 433-438. [CrossRef]

116. Papadopoulos, V.E.; Nikolopoulou, G.; Antoniadou, I.; Karachaliou, A.; Arianoglou, G.; Emmanouilidou, E.; Sardi, P.S.; Stefanis, L.; Vekrellis, K. Modulation of $\beta$-glucocerebrosidase increases $\alpha$-synuclein secretion and exosome release in mouse models of Parkinson's disease. Hum. Mol. Genet. 2018, 27, 1696-1710. [CrossRef]

117. Thomas, R.E.; Vincow, E.S.; Merrihew, G.E.; MacCoss, M.J.; Davis, M.Y.; Pallanck, L.J. Glucocerebrosidase deficiency promotes protein aggregation through dysregulation of extracellular vesicles. PLoS Genet. 2018, 14, e1007694. [CrossRef]

118. Cerri, S.; Ghezzi, C.; Sampieri, M.; Siani, F.; Avenali, M.; Dornini, G.; Zangaglia, R.; Minafra, B.; Blandini, F. The Exosomal/Total $\alpha$-Synuclein Ratio in Plasma Is Associated with Glucocerebrosidase Activity and Correlates with Measures of Disease Severity in PD Patients. Front. Cell Neurosci. 2018, 12, 125. [CrossRef]

119. 2020 Alzheimer's disease facts and figures. Alzheimer's Dement. 2020, 16, 391-460. [CrossRef]

120. Noyce, A.J.; Lees, A.J.; Schrag, A.-E. The prediagnostic phase of Parkinson's disease. J. Neurol. Neurosurg Psychiatry 2016, 87, 871-878. [CrossRef]

121. Muraoka, S.; DeLeo, A.M.; Sethi, M.K.; Yukawa-Takamatsu, K.; Yang, Z.; Ko, J.; Hogan, J.D.; Ruan, Z.; You, Y.; Wang, Y.; et al. Proteomic and biological profiling of extracellular vesicles from Alzheimer's disease human brain tissues. Alzheimer's Dement. 2020. [CrossRef] [PubMed]

122. Lim, C.Z.J.; Zhang, Y.; Chen, Y.; Zhao, H.; Stephenson, M.C.; Ho, N.R.Y.; Chen, Y.; Chung, J.; Reilhac, A.; Loh, T.P.; et al. Subtyping of circulating exosome-bound amyloid $\beta$ reflects brain plaque deposition. Nat. Commun. 2019, 10, 1144. [CrossRef] [PubMed] 
123. Cheng, L.; Vella, L.J.; Barnham, K.J.; McLean, C.; Masters, C.L.; Hill, A.F. Small RNA fingerprinting of Alzheimer's disease frontal cortex extracellular vesicles and their comparison with peripheral extracellular vesicles. J. Extracell Vesicles 2020, 9, 1766822. [CrossRef] [PubMed]

124. Mustapic, M.; Eitan, E.; Werner, J.K.; Berkowitz, S.T.; Lazaropoulos, M.P.; Tran, J.; Goetzl, E.J.; Kapogiannis, D. Plasma Extracellular Vesicles Enriched for Neuronal Origin: A Potential Window into Brain Pathologic Processes. Front. Neurosci. 2017, 11, 278. [CrossRef] [PubMed]

125. Jia, L.; Qiu, Q.; Zhang, H.; Chu, L.; Du, Y.; Zhang, J.; Zhou, C.; Liang, F.; Shi, S.; Wang, S.; et al. Concordance between the assessment of A $\beta 42$, T-tau, and P-T181-tau in peripheral blood neuronal-derived exosomes and cerebrospinal fluid. Alzheimer's Dement. 2019, 15, 1071-1080. [CrossRef]

126. Huang, Y.; Cheng, L.; Turchinovich, A.; Mahairaki, V.; Troncoso, J.C.; Pletniková, O.; Haughey, N.J.; Vella, L.J.; Hill, A.F.; Zheng, L.; et al. Influence of species and processing parameters on recovery and content of brain tissue-derived extracellular vesicles. J. Extracell Vesicles 2020, 9, 1785746. [CrossRef] [PubMed]

127. Agosta, F.; Libera, D.D.; Spinelli, E.G.; Finardi, A.; Canu, E.; Bergami, A.; Chiavetto, L.B.; Baronio, M.; Comi, G.; Martino, G.; et al. Myeloid microvesicles in cerebrospinal fluid are associated with myelin damage and neuronal loss in mild cognitive impairment and Alzheimer disease: Microglia in AD and MCI. Ann. Neurol. 2014, 76, 813-825. [CrossRef]

128. Muraoka, S.; Jedrychowski, M.P.; Yanamandra, K.; Ikezu, S.; Gygi, S.P.; Ikezu, T. Proteomic Profiling of Extracellular Vesicles Derived from Cerebrospinal Fluid of Alzheimer's Disease Patients: A Pilot Study. Cells 2020, 9, 1959. [CrossRef]

129. Liu, C.-G.; Song, J.; Zhang, Y.-Q.; Wang, P.-C. MicroRNA-193b is a regulator of amyloid precursor protein in the blood and cerebrospinal fluid derived exosomal microRNA-193b is a biomarker of Alzheimer's disease. Mol. Med. Rep. 2014, 10, 2395-2400. [CrossRef]

130. Wei, H.; Xu, Y.; Xu, W.; Zhou, Q.; Chen, Q.; Yang, M.; Feng, F.; Liu, Y.; Zhu, X.; Yu, M.; et al. Serum Exosomal miR-223 Serves as a Potential Diagnostic and Prognostic Biomarker for Dementia. Neuroscience 2018, 379, 167-176. [CrossRef]

131. Cheng, L.; Doecke, J.D.; Sharples, R.A.; Villemagne, V.L.; Fowler, C.J.; Rembach, A.; Martins, R.N.; Rowe, C.C.; Macaulay, S.L.; Masters, C.L.; et al. Prognostic serum miRNA biomarkers associated with Alzheimer's disease shows concordance with neuropsychological and neuroimaging assessment. Mol. Psychiatr. 2014, 20, 1188-1196. [CrossRef] [PubMed]

132. Yang, T.T.; Liu, C.G.; Gao, S.C.; Zhang, Y.; Wang, P.C. The Serum Exosome Derived MicroRNA-135a, -193b, and -384 Were Potential Alzheimer's Disease Biomarkers. Biomed. Environ. Sci. Bes. 2018, 31, 87-96. [CrossRef] [PubMed]

133. Agliardi, C.; Guerini, F.R.; Zanzottera, M.; Bianchi, A.; Nemni, R.; Clerici, M. SNAP-25 in Serum Is Carried by Exosomes of Neuronal Origin and Is a Potential Biomarker of Alzheimer's Disease. Mol. Neurobiol. 2019, 56, 5792-5798. [CrossRef] [PubMed]

134. Fiandaca, M.S.; Kapogiannis, D.; Mapstone, M.; Boxer, A.; Eitan, E.; Schwartz, J.B.; Abner, E.L.; Petersen, R.C.; Federoff, H.J.; Miller, B.L.; et al. Identification of preclinical Alzheimer's disease by a profile of pathogenic proteins in neurally derived blood exosomes: A case-control study. Alzheimer's Dement. 2015, 11, 600-607. [CrossRef] [PubMed]

135. Kapogiannis, D.; Mustapic, M.; Shardell, M.D.; Berkowitz, S.T.; Diehl, T.C.; Spangler, R.D.; Tran, J.; Lazaropoulos, M.P.; Chawla, S.; Gulyani, S.; et al. Association of Extracellular Vesicle Biomarkers With Alzheimer Disease in the Baltimore Longitudinal Study of Aging. JAMA Neurol. 2019, 76, 1340-1351. [CrossRef] [PubMed]

136. Guix, F.; Corbett, G.; Cha, D.; Mustapic, M.; Liu, W.; Mengel, D.; Chen, Z.; Aikawa, E.; Young-Pearse, T.; Kapogiannis, D.; et al. Detection of Aggregation-Competent Tau in Neuron-Derived Extracellular Vesicles. Int. J. Mol. Sci. 2018, 19, 663. [CrossRef]

137. Kapogiannis, D.; Boxer, A.; Schwartz, J.B.; Abner, E.L.; Biragyn, A.; Masharani, U.; Frassetto, L.; Petersen, R.C.; Miller, B.L.; Goetzl, E.J. Dysfunctionally phosphorylated type 1 insulin receptor substrate in neural-derived blood exosomes of preclinical Alzheimer's disease. FASEB J. 2014, 29, 589-596. [CrossRef]

138. Goetzl, E.J.; Kapogiannis, D.; Schwartz, J.B.; Lobach, I.V.; Goetzl, L.; Abner, E.L.; Jicha, G.A.; Karydas, A.M.; Boxer, A.; Miller, B.L. Decreased synaptic proteins in neuronal exosomes of frontotemporal dementia and Alzheimer's disease. FASEB J. 2016, 30, 4141-4148. [CrossRef] 
139. Goetzl, E.J.; Boxer, A.; Schwartz, J.B.; Abner, E.L.; Petersen, R.C.; Miller, B.L.; Kapogiannis, D. Altered lysosomal proteins in neural-derived plasma exosomes in preclinical Alzheimer disease. Neurology 2015, 85, 40-47. [CrossRef]

140. Goetzl, E.J.; Boxer, A.; Schwartz, J.B.; Abner, E.L.; Petersen, R.C.; Miller, B.L.; Carlson, O.D.; Mustapic, M.; Kapogiannis, D. Low neural exosomal levels of cellular survival factors in Alzheimer's disease. Ann. Clin. Transl. Neurol. 2015, 2, 769-773. [CrossRef]

141. Goetzl, E.J.; Abner, E.L.; Jicha, G.A.; Kapogiannis, D.; Schwartz, J.B. Declining levels of functionally specialized synaptic proteins in plasma neuronal exosomes with progression of Alzheimer's disease. FASEB J. 2018, 32, 888-893. [CrossRef] [PubMed]

142. Shi, M.; Kovac, A.; Korff, A.; Cook, T.J.; Ginghina, C.; Bullock, K.M.; Yang, L.; Stewart, T.; Zheng, D.; Aro, P.; et al. CNS tau efflux via exosomes is likely increased in Parkinson's disease but not in Alzheimer's disease. Alzheimer's Dement. 2016, 12, 1125-1131. [CrossRef] [PubMed]

143. Goetzl, E.J.; Mustapic, M.; Kapogiannis, D.; Eitan, E.; Lobach, I.V.; Goetzl, L.; Schwartz, J.B.; Miller, B.L. Cargo proteins of plasma astrocyte-derived exosomes in Alzheimer's disease. FASEB J. 2016, 30, 3853-3859. [CrossRef] [PubMed]

144. Goetzl, E.J.; Nogueras-Ortiz, C.; Mustapic, M.; Mullins, R.J.; Abner, E.L.; Schwartz, J.B.; Kapogiannis, D. Deficient neurotrophic factors of CSPG4-type neural cell exosomes in Alzheimer disease. FASEB J. 2018, 33, 231-238. [CrossRef] [PubMed]

145. Lugli, G.; Cohen, A.M.; Bennett, D.A.; Shah, R.C.; Fields, C.J.; Hernandez, A.G.; Smalheiser, N.R. Plasma Exosomal miRNAs in Persons with and without Alzheimer Disease: Altered Expression and Prospects for Biomarkers. PLoS ONE 2015, 10, e0139233. [CrossRef]

146. Cha, D.J.; Mengel, D.; Mustapic, M.; Liu, W.; Selkoe, D.J.; Kapogiannis, D.; Galasko, D.; Rissman, R.A.; Bennett, D.A.; Walsh, D.M. miR-212 and miR-132 Are Downregulated in Neurally Derived Plasma Exosomes of Alzheimer's Patients. Front. Neurosci. 2019, 13, 1208. [CrossRef] [PubMed]

147. Serpente, M.; Fenoglio, C.; D’Anca, M.; Arcaro, M.; Sorrentino, F.; Visconte, C.; Arighi, A.; Fumagalli, G.G.; Porretti, L.; Cattaneo, A.; et al. MiRNA Profiling in Plasma Neural-Derived Small Extracellular Vesicles from Patients with Alzheimer's Disease. Cells 2020, 9, 1443. [CrossRef] [PubMed]

148. Eren, E.; Hunt, J.F.V.; Shardell, M.; Chawla, S.; Tran, J.; Gu, J.; Vogt, N.M.; Johnson, S.C.; Bendlin, B.B.; Kapogiannis, D. Extracellular vesicle biomarkers of Alzheimer's disease associated with sub-clinical cognitive decline in late middle age. Alzheimer's Dement. 2020, 16, 1293-1304. [CrossRef]

149. Bedse, G.; Domenico, F.D.; Serviddio, G.; Cassano, T. Aberrant insulin signaling in Alzheimer's disease: Current knowledge. Front. Neurosci. 2015, 9, 204. [CrossRef]

150. Mullins, R.J.; Mustapic, M.; Goetzl, E.J.; Kapogiannis, D. Exosomal biomarkers of brain insulin resistance associated with regional atrophy in Alzheimer's disease: Brain IR and AD Atrophy. Hum. Brain Mapp. 2017, 38, 1933-1940. [CrossRef]

151. Cheng, L.; Sharples, R.A.; Scicluna, B.J.; Hill, A.F. Exosomes provide a protective and enriched source of miRNA for biomarker profiling compared to intracellular and cell-free blood. J. Extracell Vesicles 2014, 3, 23743. [CrossRef] [PubMed]

152. Baker, L.D.; Barsness, S.M.; Borson, S.; Merriam, G.R.; Friedman, S.D.; Craft, S.; Vitiello, M.V. Effects of Growth Hormone-Releasing Hormone on Cognitive Function in Adults With Mild Cognitive Impairment and Healthy Older Adults: Results of a Controlled Trial. Arch. Neurol. 2012, 69, 1420. [CrossRef] [PubMed]

153. Winston, C.N.; Goetzl, E.J.; Baker, L.D.; Vitiello, M.V.; Rissman, R.A. Growth Hormone-Releasing Hormone Modulation of Neuronal Exosome Biomarkers in Mild Cognitive Impairment. J. Alzheimer's Dis. 2018, 66, 971-981. [CrossRef] [PubMed]

154. Craft, S.; Baker, L.D.; Montine, T.J.; Minoshima, S.; Watson, G.S.; Claxton, A.; Arbuckle, M.; Callaghan, M.; Tsai, E.; Plymate, S.R.; et al. Intranasal Insulin Therapy for Alzheimer Disease and Amnestic Mild Cognitive Impairment: A Pilot Clinical Trial. Arch. Neurol. 2012, 69, 29. [CrossRef] [PubMed]

155. Mustapic, M.; Tran, J.; Craft, S.; Kapogiannis, D. Extracellular Vesicle Biomarkers Track Cognitive Changes Following Intranasal Insulin in Alzheimer's Disease. J. Alzheimer's Dis. 2019, 69, 489-498. [CrossRef] [PubMed]

156. Tomlinson, P.R.; Zheng, Y.; Fischer, R.; Heidasch, R.; Gardiner, C.; Evetts, S.; Hu, M.; Wade-Martins, R.; Turner, M.R.; Morris, J.; et al. Identification of distinct circulating exosomes in Parkinson's disease. Ann. Clin. Transl. Neurol. 2015, 2, 353-361. [CrossRef] 
157. Picca, A.; Guerra, F.; Calvani, R.; Marini, F.; Biancolillo, A.; Landi, G.; Beli, R.; Landi, F.; Bernabei, R.; Bentivoglio, A.; et al. Mitochondrial Signatures in Circulating Extracellular Vesicles of Older Adults with Parkinson's Disease: Results from the EXosomes in PArkiNson's Disease (EXPAND) Study. J. Clin. Med. 2020, 9, 504. [CrossRef]

158. Shi, M.; Liu, C.; Cook, T.J.; Bullock, K.M.; Zhao, Y.; Ginghina, C.; Li, Y.; Aro, P.; Dator, R.; He, C.; et al. Plasma exosomal $\alpha$-synuclein is likely CNS-derived and increased in Parkinson's disease. Acta Neuropathol. 2014, 128, 639-650. [CrossRef]

159. Zhao, Z.-H.; Chen, Z.-T.; Zhou, R.-L.; Zhang, X.; Ye, Q.-Y.; Wang, Y.-Z. Increased DJ-1 and $\alpha$-Synuclein in Plasma Neural-Derived Exosomes as Potential Markers for Parkinson's Disease. Front. Aging Neurosci. 2019, 10, 438. [CrossRef]

160. Jiang, C.; Hopfner, F.; Katsikoudi, A.; Hein, R.; Catli, C.; Evetts, S.; Huang, Y.; Wang, H.; Ryder, J.W.; Kuhlenbaeumer, G.; et al. Serum neuronal exosomes predict and differentiate Parkinson's disease from atypical parkinsonism. J. Neurol. Neurosurg Psychiatry 2020, 91, 720-729. [CrossRef]

161. Kitamura, Y.; Kojima, M.; Kurosawa, T.; Sasaki, R.; Ichihara, S.; Hiraku, Y.; Tomimoto, H.; Murata, M.; Oikawa, S. Proteomic profiling of exosomal proteins for blood-based biomarkers in Parkinson's disease. Neuroscience 2018, 392, 121-128. [CrossRef] [PubMed]

162. Yao, Y.F.; Qu, M.W.; Li, G.C.; Zhang, F.B.; Rui, H.C. Circulating exosomal miRNAs as diagnostic biomarkers in Parkinson's disease. Eur. Rev. Med. Pharmaco. 2018, 22, 5278-5283. [CrossRef]

163. Gualerzi, A.; Picciolini, S.; Carlomagno, C.; Terenzi, F.; Ramat, S.; Sorbi, S.; Bedoni, M. Raman profiling of circulating extracellular vesicles for the stratification of Parkinson's patients. Nanomed. Nanotechnol. Biol. Med. 2019, 22, 102097. [CrossRef] [PubMed]

164. Jiang, R.; Rong, C.; Ke, R.; Meng, S.; Yan, X.; Ke, H.; Wu, S. Differential proteomic analysis of serum exosomes reveals alterations in progression of Parkinson disease. Medicine 2019, 98, e17478. [CrossRef]

165. Picca, A.; Guerra, F.; Calvani, R.; Bucci, C.; Monaco, M.R.L.; Bentivoglio, A.R.; Landi, F.; Bernabei, R.; Marzetti, E. Mitochondrial-Derived Vesicles as Candidate Biomarkers in Parkinson's Disease: Rationale, Design and Methods of the EXosomes in PArkiNson Disease (EXPAND) Study. Int. J. Mol. Sci. 2019, 20, 2373. [CrossRef]

166. Cao, X.-Y.; Lu, J.-M.; Zhao, Z.-Q.; Li, M.-C.; Lu, T.; An, X.-S.; Xue, L.-J. MicroRNA biomarkers of Parkinson's disease in serum exosome-like microvesicles. Neurosci. Lett. 2017, 644, 94-99. [CrossRef]

167. Fraser, K.B.; Moehle, M.S.; Daher, J.P.L.; Webber, P.J.; Williams, J.Y.; Stewart, C.A.; Yacoubian, T.A.; Cowell, R.M.; Dokland, T.; Ye, T.; et al. LRRK2 secretion in exosomes is regulated by 14-3-3. Hum. Mol. Genet. 2013, 22, 4988-5000. [CrossRef]

168. Ho, D.H.; Yi, S.; Seo, H.; Son, I.; Seol, W. Increased DJ-1 in Urine Exosome of Korean Males with Parkinson's Disease. Biomed. Res. Int. 2014, 2014, 704678. [CrossRef]

169. Fraser, K.B.; Moehle, M.S.; Alcalay, R.N.; West, A.B.; Consortium, L.C. Urinary LRRK2 phosphorylation predicts parkinsonian phenotypes in G2019S LRRK2 carriers. Neurology 2016, 86, 994-999. [CrossRef]

170. Fraser, K.B.; Rawlins, A.B.; Clark, R.G.; Alcalay, R.N.; Standaert, D.G.; Liu, N.; Parkinson's Disease Biomarker Program Consortium; West, A.B. Ser(P)-1292 LRRK2 in urinary exosomes is elevated in idiopathic Parkinson's disease. Mov. Disord. 2016, 31, 1543-1550. [CrossRef]

171. Wang, S.; Kojima, K.; Mobley, J.A.; West, A.B. Proteomic analysis of urinary extracellular vesicles reveal biomarkers for neurologic disease. Ebiomedicine 2019, 45, 351-361. [CrossRef]

172. Cao, Z.; Wu, Y.; Liu, G.; Jiang, Y.; Wang, X.; Wang, Z.; Zhang, J.; Feng, T. $\alpha$-synuclein in salivary extracellular vesicles as a potential biomarker of Parkinson's disease. Neurosci. Lett. 2018, 696, 114-120. [CrossRef] [PubMed]

173. Rani, K.; Mukherjee, R.; Singh, E.; Kumar, S.; Sharma, V.; Vishwakarma, P.; Bharti, P.S.; Nikolajeff, F.; Dinda, A.K.; Goyal, V.; et al. Neuronal exosomes in saliva of Parkinson's disease patients: A pilot study. Parkinsonism. Relat. Disord. 2019, 67, 21-23. [CrossRef] [PubMed]

174. Tolosa, E.; Vila, M.; Klein, C.; Rascol, O. LRRK2 in Parkinson disease: Challenges of clinical trials. Nat. Rev. Neurol. 2020, 16, 97-107. [CrossRef] [PubMed]

175. Athauda, D.; Maclagan, K.; Skene, S.S.; Bajwa-Joseph, M.; Letchford, D.; Chowdhury, K.; Hibbert, S.; Budnik, N.; Zampedri, L.; Dickson, J.; et al. Exenatide once weekly versus placebo in Parkinson's disease: A randomised, double-blind, placebo-controlled trial. Lancet 2017, 390, 1664-1675. [CrossRef] 
176. Athauda, D.; Gulyani, S.; Karnati, H.k.; Li, Y.; Tweedie, D.; Mustapic, M.; Chawla, S.; Chowdhury, K.; Skene, S.S.; Greig, N.H.; et al. Utility of Neuronal-Derived Exosomes to Examine Molecular Mechanisms That Affect Motor Function in Patients With Parkinson Disease. JAMA Neurol. 2019, 76, 420-429. [CrossRef]

177. Dubois, B.; Feldman, H.H.; Jacova, C.; Hampel, H.; Molinuevo, J.L.; Blennow, K.; DeKosky, S.T.; Gauthier, S.; Selkoe, D.; Bateman, R.; et al. Advancing research diagnostic criteria for Alzheimer's disease: The IWG-2 criteria. Lancet Neurol. 2014, 13, 614-629. [CrossRef]

178. Jack, C.R.; Bennett, D.A.; Blennow, K.; Carrillo, M.C.; Dunn, B.; Haeberlein, S.B.; Holtzman, D.M.; Jagust, W.; Jessen, F.; Karlawish, J.; et al. NIA-AA Research Framework: Toward a biological definition of Alzheimer's disease. Alzheimer's Dement. 2018, 14, 535-562. [CrossRef]

179. Niemantsverdriet, E.; Valckx, S.; Bjerke, M.; Engelborghs, S. Alzheimer's disease CSF biomarkers: Clinical indications and rational use. Acta Neurol. Belg. 2017, 117, 591-602. [CrossRef]

180. Postuma, R.B.; Berg, D.; Stern, M.; Poewe, W.; Olanow, C.W.; Oertel, W.; Obeso, J.; Marek, K.; Litvan, I.; Lang, A.E.; et al. MDS clinical diagnostic criteria for Parkinson's disease: MDS-PD Clinical Diagnostic Criteria. Mov. Disord. 2015, 30, 1591-1601. [CrossRef]

181. Duits, F.H.; Martinez-Lage, P.; Paquet, C.; Engelborghs, S.; Lleó, A.; Hausner, L.; Molinuevo, J.L.; Stomrud, E.; Farotti, L.; Ramakers, I.H.G.B.; et al. Performance and complications of lumbar puncture in memory clinics: Results of the multicenter lumbar puncture feasibility study. Alzheimer's Dement. 2015, 12, 154-163. [CrossRef] [PubMed]

182. Zetterberg, H.; Burnham, S.C. Blood-based molecular biomarkers for Alzheimer's disease. Mol. Brain 2019, 12, 26. [CrossRef] [PubMed]

183. Hampel, H.; O’Bryant, S.E.; Molinuevo, J.L.; Zetterberg, H.; Masters, C.L.; Lista, S.; Kiddle, S.J.; Batrla, R.; Blennow, K. Blood-based biomarkers for Alzheimer disease: Mapping the road to the clinic. Nat. Rev. Neurol. 2018, 14, 639-652. [CrossRef] [PubMed]

184. Barbour, R.; Kling, K.; Anderson, J.P.; Banducci, K.; Cole, T.; Diep, L.; Fox, M.; Goldstein, J.M.; Soriano, F.; Seubert, P.; et al. Red Blood Cells Are the Major Source of Alpha-Synuclein in Blood. Neurodegener. Dis. 2008, 5, 55-59. [CrossRef] [PubMed]

185. Saint-Pol, J.; Gosselet, F.; Duban-Deweer, S.; Pottiez, G.; Karamanos, Y. Targeting and Crossing the Blood-Brain Barrier with Extracellular Vesicles. Cells 2020, 9, 851. [CrossRef] [PubMed]

186. Roux, Q.; Deun, J.; Dedeyne, S.; Hendrix, A. The EV-TRACK summary add-on: Integration of experimental information in databases to ensure comprehensive interpretation of biological knowledge on extracellular vesicles. J. Extracell Vesicles 2020, 9, 1699367. [CrossRef]

187. Witwer, K.W.; Buzás, E.I.; Bemis, L.T.; Bora, A.; Lässer, C.; Lötvall, J.; Hoen, E.N.N.-t.; Piper, M.G.; Sivaraman, S.; Skog, J.; et al. Standardization of sample collection, isolation and analysis methods in extracellular vesicle research. J. Extracell Vesicles 2013, 2, 20360. [CrossRef]

188. Lee, S.; Mankhong, S.; Kang, J.-H. Extracellular Vesicle as a Source of Alzheimer's Biomarkers: Opportunities and Challenges. Int. J. Mol. Sci. 2019, 20, 1728. [CrossRef]

189. Ayers, L.; Pink, R.; Carter, D.R.F.; Nieuwland, R. Clinical requirements for extracellular vesicle assays. J. Extracell Vesicles 2019, 8, 1593755. [CrossRef]

Publisher's Note: MDPI stays neutral with regard to jurisdictional claims in published maps and institutional affiliations.

(C) 2020 by the authors. Licensee MDPI, Basel, Switzerland. This article is an open access article distributed under the terms and conditions of the Creative Commons Attribution (CC BY) license (http://creativecommons.org/licenses/by/4.0/). 